\title{
The Afghanistan Analyst Conflict Bibliography
}

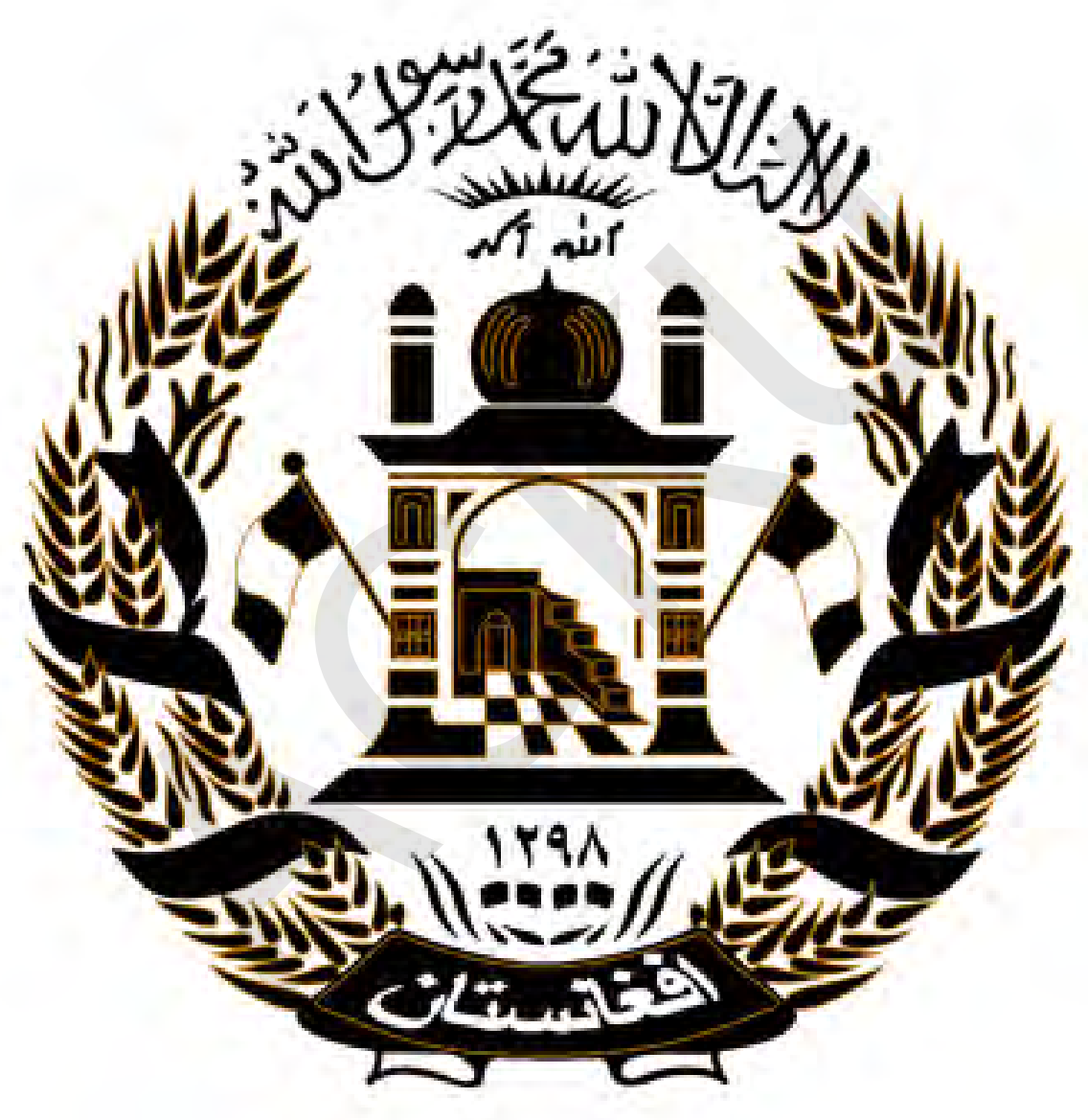

Special Edition - February 2012

Compiled by Christian Bleuer 


\title{
The Afghanistan Analyst Conflict Bibliography
}

\author{
February 2012
}

Compiled by: Christian Bleuer

contact@afghanistan-analyst.org

Published by The Afghanistan Analyst

http://afghanistan-analyst.org 


\section{Contents}

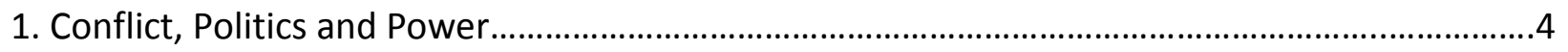

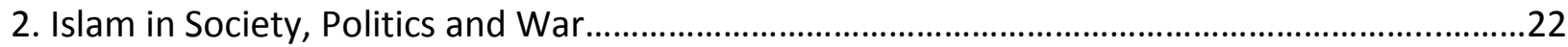

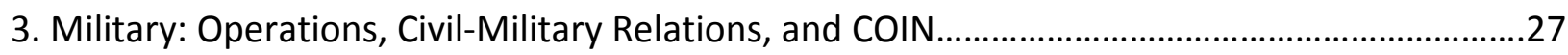

4. Security Sector: DDR, Militias, ANA, ANP, and Security Contractors..........................................48

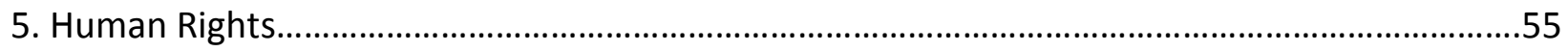

6. Refugees and Internally Displaced Persons................................................................................59

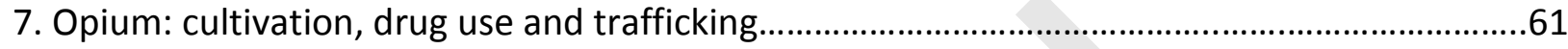

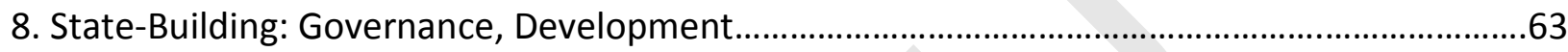

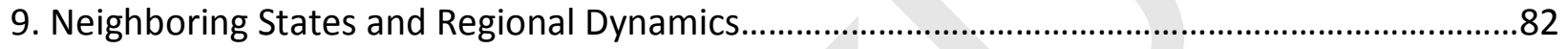

\section{Introduction to the Special Edition}

The regular annual bibliography has become, at almost 250 pages, unwieldy for many. In response I have created a much shorter and more focused bibliography. Based on feedback, it seems that the highest demand is for recent publications that analyze conflict issues. I have given this a rather wide definition, but I have had to exclude several bibliography sections that are included in the regular version. Within some sections older sources have been removed. In addition, non-academic press books have been eliminated.

The publications included in this version are up-to-date as of the beginning of February 2012. However, I do not claim to have included every relevant publication. In terms of the regular annual bibliography, I do take suggestions for sources to include, as long as they are long-form articles and reports, preferably from peer-reviewed journals or institutes. In terms of books I only include analytical books, not narratives or personal stories.

As for comments about the scope and quality of the bibliography, I do welcome suggestions and criticisms. Just please keep in mind that this bibliography is a free service provided by one individual who works in their spare time with no funding whatsoever. There is a limit to how comprehensive these bibliographies can be.

Christian Bleuer

Canberra, Australia

5 February 2012 


\section{Conflict, Politics and Power}

\section{Books}

Adamec, Ludwig W. 2006. Historical Dictionary of Afghan Wars, Revolutions and Insurgencies. New Delhi: Manas Publications.

Amin, Agha H., et al. 2010. The Development of Taliban Factions in Afghanistan and Pakistan: $A$ Geographical Account. Mellen Press.

Azoy, Whitney. 1982. Buzkashi: Game and Power in Afghanistan. Philadelphia: The University of Pennsylvania Press.

Banuazizi, Ali and Myron Weiner (Eds.) 1986. The State, Religion, and Ethnic Politics: Afghanistan, Iran, and Pakistan. Syracuse: Syracuse University Press.

Barfield, Thomas. 2010. Afghanistan: A Cultural and Political History. Princeton Uni Press.

Barry, Michael. 2006. A History of Modern Afghanistan. Cambridge University Press.

Bashir, Shahzad and Robert D. Crews (editors). 2012. Under the Drones: Modern Lives in the Afghanistan-Pakistan Borderlands. Harvard University Press.

Bhatia, Michael and Mark Sedra. 2008. Afghanistan, Arms and Conflict: Armed Groups, Disarmament and Security in a Post-war Society. Routledge.

Brown, Vahid and Don Rassler. 2012. Fountainhead of Jihad: The Haqqani Nexus, 1973-2010. Hurst \& Co.

Canfield, Robert L. and Gabriele Rasuly-Paleczek (editors). 2010. Ethnicity, Authority, and Power in Central Asia: New Games Great and Small. Routledge.

Coburn, Noah. 2011. Bazaar Politics: Power and Pottery in an Afghan Market Town. Stanford University Press. 
Coll, Steve. 2004. Ghost Wars: The Secret History of the CIA, Afghanistan, and Bin Laden, from the Soviet Invasion to September 10, 2001. Penguin.

Crews, Robert D. and Tarzi, Amin. 2008. The Taliban and the Crisis of Afghanistan. Harvard University Press.

Dorronsoro, Gilles. 2005. Revolution Unending: Afghanistan, 1979 to the Present. New York: Columbia University Press.

Edwards, David B. 2002. Before Taliban: Genealogies of the Afghan Jihad. Berkeley, CA: University of California Press.

Edwards, David B. 1996. Heroes of the Age: Moral Fault Lines on the Afghan Frontier. Berkeley, CA: University of California Press.

Emadi, Hafizullah. 2010. Dynamics of Political Development in Afghanistan: The British, Russian, and American Invasions. Palgrave Macmillan.

Ewans, Martin. 2005. Conflict in Afghanistan: Studies in Asymmetric Warfare. Routledge.

Giustozzi, Antonio. 2009. Empires of Mud: Wars and Warlords of Afghanistan. Hurst/Columbia University Press.

Giustozzi, Antonio (ed.). 2009. Decoding the New Taliban: Insights from the Afghan Field. Hurst/Columbia University Press.

Giustozzi, Antonio. 2008. Koran, Kalashnikov and Laptop: The Neo-Taliban Insurgency in Afghanistan. New York: Columbia University Press.

Giustozzi, Antonio. 2000. War, Politics, and Society in Afghanistan: 1978-1992. Washington: Georgetown University Press.

Goodson, Larry P. 2001. Afghanistan's Endless War: State Failure, Regional Politics, and the Rise of the Taliban. University of Washington Press.

Hanifi, Shah Mahmoud (editor). 2012. Power Hierarchies and Hegemony in Afghanistan: State Building, Ethnic Minorities and Identity in Central Asia. Tauris.

Hopkins, Ben. 2008. The Makings of Modern Afghanistan. Palgrave Macmillan.

Hussain, Rizwan. 2005. Pakistan And The Emergence Of Islamic Militancy in Afghanistan. Ashgate publishing.

Jones, Seth. 2009. In the Graveyard of Empires: America's War in Afghanistan. W.W. Norton. 
Kalinovsky, Artemy M. 2011. A Long Goodbye: The Soviet Withdrawal from Afghanistan. Harvard University Press.

Khan, Riaz M. 2011. Afghanistan and Pakistan: Conflict, Extremism, and Resistance to Modernity. John Hopkins University Press.

Maley, William. 2007. Rescuing Afghanistan. London: Hurst \& Company.

Maley, William. 2002. The Afghan Wars. New York: Palgrave Macmillan.

Maley, William (editor). 1998. Fundamentalism Reborn? Afghanistan and the Taliban. New York: New York University Press.

Malik, Hafeez. 2008. US Relations With Afghanistan and Pakistan: The Imperial Dimension. Oxford University Press.

Marsden, Magnus and Benjamin Hopkins (editors). 2012. Beyond Swat: History, Society and Economy along the Afghanistan-Pakistan Frontier. Columbia University Press.

Marsden, Magnus and Benjamin D. Hopkins. 2012. Fragments of the Afghan Frontier. Columbia University Press.

Misdaq, Nabi. 2006. Afghanistan: Political Frailty and Foreign Interference. Routledge.

Noelle-Karimi, Christine and Conrad Schetter and Reinhard Schlagintweit (editors) 2002.

Afghanistan - A Country without a State? Frankfurt am Main, Germany: IKO.

Notin, Jean-C. 2011. La Guerre de l'ombre des Français en Afghanistan: 1979-2011. Fayard.

Qassem, Ahmad Shayeq. 2009. Afghanistan's Political Stability: A Dream Unrealised. Ashgate.

Rais, Rasul Bakhsh. 2008. Recovering the Frontier Stage: War, Ethnicity, and State in Afghanistan. Lexington Books.

Rasanayagam, Angelo. 2003. Afghanistan: A Modern History. London: I. B. Tauris.

Rashid, Ahmed. 2009. Descent into Chaos: The U.S. and the Disaster in Pakistan, Afghanistan, and Central Asia. Penguin.

Rashid, Ahmed. 2000. Taliban: Militant Islam, Oil, and Fundamentalism in Central Asia. New Haven, CT: Yale University Press.

Roberts, Jeffrey J. 2003. The Origins of Conflict in Afghanistan. Westport, CT: Praeger. 
Rothstein, Hy and John Arguilla (editors). 2012. Afghan Endgames: Strategy and Policy Choices for America's Longest War. Georgetown University Press.

Roy, Olivier. 1995. Afghanistan: From Holy War to Civil War. Princeton: Darwin Press.

Roy, Olivier. 1990. Islam and Resistance in Afghanistan. Cambridge University Press.

Rubin, Barnett R. 2012. Afghanistan in the Post-Cold War Era. Oxford University Press.

Rubin, Barnett. 1995. The Search for Peace in Afghanistan: From Buffer State to Failed State. New Haven, CT: Yale University Press.

Rubin, Barnett. 1995. The Fragmentation of Afghanistan: State Formation and Collapse in the International System. New Haven, CT: Yale University Press.

Saikal, Amin. 2004. Modern Afghanistan: A History of Struggle and Survival. I. B. Tauris.

Shahrani, M. Nazif and Robert L Canfield (Eds.) 1984. Revolutions and Rebellions in Afghanistan: Anthropological Perspectives. Berkeley: University of California.

Sinno, Abdulkader. 2008. Organizations at War in Afghanistan and Beyond. ICornell Uni Press.

Strick van Linschoten, Alex and Felix Kuehn. 2012. An Enemy We Created: The Myth of the Taliban / Al-Qaeda Merger in Afghanistan, 1970-2010. Hurst.

Williams, Brian Glyn. 2011. Afghanistan Declassified: A Guide to America's Longest War. University of Pennsylvania Press.

Zaeef, Abdul Salam. 2010. My Life with the Taliban. Edited by Alex Strick van Linschoten and Felix Kuehn. Hurst/Columbia University Press.

\section{Articles, reports, and chapters in books}

Adeny, Katharine. 2008. 'Constitutional Design and the Political Salience of "Community" in Afghanistan: Prospects for the Emergence of Ethnic Conflicts in Post-Taliban Afghanistan', Asian Survey, Vol. 48, Issue 4, pp. 535-557.

Akrami, Mary. 2009. 'How to Bury the Hatchet: Efforts to Reconcile', Swedish Committee for Afghanistan Conference: Peace Building in Afghanistan. Download PDF. 
ANSO. 2011. 'ANSO Quarterly Data Report, Q.4', Afghan NGO Safety Office. PDF.

Aras, Bulent and Sule Toktas. 2008. 'Afghanistan's Security: Political Process, State-Building and Narcotics', Middle East Policy, Vol. 15 Issue 2.

Atran, Scott. 2010. 'A Question of Honour: Why the Taliban Fight and What to Do About It', Asian Journal of Social Science, Vol. 38.

Azerbaijani Moghaddam, Sippi. 2009. 'Northern Exposure for the Taliban', in Antonio Giustozzi (ed.) Decoding the New Taliban: Insights from the Afghan Field. Columbia University Press.

Azoy, Whitney. 2003 'Masood's Parade: Iconography, Revitalization and Ethnicity in Afghanistan', Expedition, Vol. 45, No. 1.

Barakat, Sultan and S. Zyck. 2010. 'Afghanistan's insurgency and the viability of a political solution', Studies in Conflict and Terrorism, Vol. 33, No. 3.

Barfield, Thomas. 2005. 'Afghanistan is Not the Balkans: Ethnicity and its Political Consequences from a Central Asian Perspective', Central Eurasian Studies Review, Volume 4, Number 1, Winter 2005. Download PDF.

Bergh, Gina et al. 2009. 'Conflict analysis: Jaghori and Malistan districts, Ghazni province', CPAU. Download PDF.

Berman, Eli, et al. 2011. 'Do Working Men Rebel? Insurgency and Unemployment in Afghanistan, Iraq and the Philippines', Journal of Conflict Resolution (March 2011).

van Bijlert, Martine. 2010. 'Militancy and Conflict in Zabul and Uruzgan', New America Foundation. Download PDF.

van Bijlert, Martine. 2009. 'Unruly Commanders and Violent Power Struggles: Taliban Networks in Uruzgan', in Antonio Giustozzi (ed.) Decoding the New Taliban: Insights from the Afghan Field. Columbia University Press.

Brahimi, Alia. 2010. 'The Taliban's Evolving Ideology', LSE. Download PDF.

Canfield, Robert L. 2010. 'Efficacy and Hierarchy: Practices in Afghanistan as an Example', in Ethnicity, Authority, and Power in Central Asia: New Games Great and Small. Edited by Robert L. Canfield and Gabriele Rasuly-Paleczek. Routledge.

Canfield, Robert L. 2008. 'Fraternity, Power, and Time in Central Asia', in Robert D Crews and Amin Tarzi (editors). The Taliban and the Crisis of Afghanistan. Harvard University Press. 
Canfield, Robert L. 1988. 'Afghanistan's social identities crisis', in Jean-Pierre Digard (editor), Le Fait Ethnique en Iran et en Afghanistan. Paris.

Canfield, Robert L. 1986. 'Ethnic, Regional, and Sectarian Alignments in Afghanistan' in The State, Religion, and Ethnic Politics: Afghanistan, Iran, and Pakistan. Ali Banuazizi and Myron Weiner (Eds.) Syracuse: Syracuse University Press.

Centlivres, P. and M. Centlivres-Demont. 2000. 'State, National Awareness and Levels of Identity in Afghanistan from Monarchy to Islamic State', in Central Asian Survey, Vol.19(3-4).

Chandra, Vishal. 2011. 'The Evolving Politics of Taliban Reintegration and Reconciliation in Afghanistan', Strategic Analysis, Volume 35, Issue 5.

Chorev, Matan and J. Sherman. 2010. 'The Prospects for Security and Political Reconciliation in Afghanistan: Local, National, and Regional Perspectives', Institute for Global Leadership. PDF.

Coghlan, Tom. 2009. 'The Taliban in Helmand: An Oral History', in Antonio Giustozzi (ed.) Decoding the New Taliban: Insights from the Afghan Field. Hurst/Columbia.

Crews, Robert D. 2008. 'Moderate Taliban?', in Robert D Crews and Amin Tarzi (editors). The Taliban and the Crisis of Afghanistan. Harvard University Press.

Dansie, Grant. 2009. 'Enemies, Irregular Adversaries, Spoilers, Non-compliant Actors: How the Definition of Actors Influences Afghanistan Strategies', Norwegian Institute of International Affairs. NUPI Working Paper 756. Download PDF.

Davis, Anthony. 1998. 'How the Taliban became a Military Force', in William Maley (editor) Fundamentalism Reborn? Afghanistan and the Taliban. NYU Press.

Dearing, Matt. 2010. 'Like Red Tulips at Springtime: Understanding the Absence of Female Martyrs in Afghanistan', Studies in Conflict \& Terrorism, Vol. 33, No. 12.

Dearing, Matthew. 2008. 'Examining the Suicide Terror Movement in Afghanistan', The Culture and Conflict Review, Summer 2008. Download PDF.

Dennys, Christian and I. Zaman. 2009. 'Trends in local Afghan conflicts', CPAU. PDF.

Devlin, Lawrence et al. 2009. 'Conflict analysis: Kunduz city, Kunduz province', CPAU. Download $\underline{\text { PDF. }}$

Dietl, Gulshan. 2004. 'War, peace and the warlords: the case of Ismail Khan of Herat in Afghanistan', Alternatives, Vol. 3, No. 2\&3, pages 41-66. Download PDF. 
Dorronsoro, Gilles. 2007. 'Kabul at War (1992-1996): State, Ethnicity and Social Classes', South Asia Multidisciplinary Academic Journal, 14. Download PDF.

Dorronsoro, Gilles. 2003. 'Afghanistan: the Delusions of Victory', IPG 2/2003. PDF.

Dressler, Jeffrey. 2011. 'Counterinsurgency in Helmand', Institute for the Study of War. PDF.

Dressler, Jeffrey A. 2010. 'The Haqqani Network: From Pakistan to Afghanistan', ISW

Afghanistan Report No. 6. Download PDF.

Elias, Mohammad Osman Tariq. 2009. 'The Resurgence of the Taliban in Kabul: Logar and Wardak', in Antonio Giustozzi (ed.) Decoding the New Taliban: Insights from the Afghan Field. Hurst/Columbia University Press.

Emadi, Hafizullah. 2001. 'Radical political movements in Afghanistan and their politics of peoples' empowerment and liberation', Central Asian Survey, 20(4), pp. $427-450$.

Esser, Daniel. 2007. 'Target Kabul: human insecurity in the Afghan capital', in Human Security for an Urban Century: Local Challenges, Global Perspectives. Ottawa: Foreign Affairs and International Trade Canada.

Esser, Daniel. 2004. 'The City as Arena, Hub and Prey: Patterns of Violence in Kabul and Karachi', Environment \& Urbanization, Vol. 16, No. 2.

Fair, C. Christine. 2010. 'Afghanistan's Flawed Elections: Implications for the Insurgency', in The Afghanistan-Pakistan Theater: Militant Islam, Security \& Stability. Edited by Edited by Daveed Gartenstein-Ross \& Clifford D. May. Washington: FDD Press. Download PDF.

Forsberg, Carl. 2010. 'Politics and Power in Kandahar', Institute for the Study of War. PDF.

Forsberg, Carl. 2009. 'The Taliban's Campaign for Kandahar', Afghanistan Report \#3. Institute for the Study of War. Download PDF.

Geller, Armando and Shah Jamal Alam. 2010. 'A Socio-Political and-Cultural Model of the War in Afghanistan', International Studies Review, Vol. 12, No. 1.

Geller, Armando and Scott Moss. 2008. 'Growing Qawm: An Evidence Driven Declarative Model of Afghan Power Structures', Advances in Complex Systems, 11(2).

Giustozzi, Antonio and Niamatullah Ibrahimi. 2012. 'Thirty years of conflict: drivers of antigovernment mobilisation in Afghanistan, 1978-2011', AREU. Download PDF.

Giustozzi, Antonio and Christoph Reuter. 2011. 'The Insurgents of the Afghan North', Afghanistan Analysts Network. Download PDF. 
Giustozzi, Antonio. 2011. 'Double-edged swords: armies, elite bargaining and state-building', Crisis States Research Centre, Working Paper no. 86. Download PDF.

Giustozzi, Antonio. 2010. 'The Taliban Beyond the Pashtuns', CIGI, The Afghanistan Papers No. 5. Download PDF.

Giustozzi, Antonio. 2010. 'The 'Great Fears' of Afghanistan: How wild rumours shape politics', IDEAS Today, Issue 4. Download PDF.

Giustozzi, Antonio. 2010. 'Negotiating with the Taliban: Issues and Prospects', The Century Foundation. Download PDF.

Giustozzi, Antonio and Christoph Reuter. 2010. 'The Northern Front: The Afghan insurgency spreading beyond the Pashtuns', Afghanistan Analysts Network. PDF.

Giustozzi, Antonio. 2010. 'Between Patronage and Rebellion: Student Politics in Afghanistan', AREU. Download PDF.

Giustozzi, Antonio, and Christoph Reuter. 2010. 'The Northern Front: The Afghan Insurgency Spreading beyond the Pashtuns', Afghanistan Analysts Network. PDF.

Giustozzi, Antonio. 2009. 'The Taliban's Marches: Heart, Farah, Baghis and Ghor', in Antonio Giustozzi (ed.) Decoding the New Taliban: Insights from the Afghan Field. Columbia Uni Press.

Giustozzi, Antonio. 2009. 'Afghanistan: 'friction' between civilizations', in Stig Hansen et al (eds.), The borders of Islam: exploring Huntington's faultlines, from Al-Andalus to the virtual Ummah. Hurst, London, UK.

Giustozzi, Antonio. 2009. 'One or many? The Issue of the Taliban's Unity and Disunity', Pakistan Security Research Unit. Download PDF.

Giustozzi, Antonio. 2009. 'The eye of the Storm: Cities in the Vortex of Afghanistan's Civil Wars', Crisis States Research Centre, Working Paper No. 62. Download PDF.

Giustozzi, Antonio. 2009. 'The Pygmy who turned into a Giant: The Afghan Taliban in 2009', in Afghanistan: Now You See Me? IDEAS Strategic Update 001. Download PDF.

Giustozzi, Antonio. 2008. 'Armed politics and political competition in Afghanistan', CMI Research Paper. Download PDF.

Giustozzi, Antonio. 2008. 'Afghanistan: political parties or militia fronts?', in de Zeeuw, J, (ed.) From soldiers to politicians: transforming rebel movements after civil war. Lynne Rienner. 
Giustozzi, Antonio. 2007. 'War and Peace Economies of Afghanistan's Strongmen', International Peacekeeping, Vol. 14, No. 1.

Giustozzi, Antonio. 2007. 'The Missing Ingredient: Non-Ideological Insurgency and State Collapse in Western Afghanistan, 1979-1992', Crisis States PWorking Paper, No. 11. PDF.

Giustozzi, Antonio. 2006. 'Genesis of a Prince: The Rise of Ismail Khan in Western Afghanistan, 1979-1992', Crisis States Programme Working Paper Series \#2, No. 4. Download PDF.

Giustozzi, Antonio and Noor Ullah. 2006. "'Tribes" and Warlords in Southern Afghanistan, 19802005', Crisis States Programme Working Paper, No. 7. PDF.

Giustozzi, Antonio. 2005. 'The Ethnicisation of an Afghan Faction: Junbesh-I-Milli from its Origins to the Presidential Elections', Crisis States Programme Working Paper, No. 67. PDF.

Giustozzi, Antonio. 2005. 'Warlords into Businessmen: the Afghan Transition, 2002-2005', Paper presented at the "Transforming War Economies" Seminar. Download PDF.

Giustozzi, Antonio. 2005 'The Debate on Warlordism: The Importance of Military Legitimacy', Crisis States Programme Discussion Paper, No. 13. Download PDF.

Giustozzi, Antonio. 2003. 'Respectable Warlords? The Politics of State-Building in Post-Taleban Afghanistan', Crisis States Programme Working Paper, No. 33. Download PDF.

Glatzer, Bernt. 2002. 'Centre and Periphery in Afghanistan: New Identities in a Broken State', Sociologus, winter.

Glatzer, Bernt. 2001. 'War and Boundaries in Afghanistan: Significance and Relativity of Local and Social Boundaries', Weld des Islams, Vol. 41, No. 3. Download PDF.

Gopal, Anand. 2010. 'The Battle for Afghanistan: Militancy and Conflict in Kandahar', New America Foundation. Download PDF.

Gopal, Anand and Matthew DuPee. 2010. 'Tensions Rise Between Hizb-i-Islami and the Taliban in Afghanistan', CTC Sentinel, Vol. 3, No. 8. Download PDF.

Grau, Lester W. 2007. 'Breaking Contact Without Leaving Chaos: The Soviet Withdrawal from Afghanistan', The Journal of Slavic Military Studies, Vol. 20, No. 2.

Hansen, Cole et al. 2009. 'Conflict analysis: Baharak district, Badakhshan province', Cooperation for Peace and Unity, February 2009. Download PDF.

Harpviken, Kristian Berg. 2010. ‘Understanding Warlordism: Three Biographies from Afghanistan's Southeastern Areas', International Peace Research Institute. PDF. 
Harpviken, Kristian Berg. 2006. 'The Transnationalization of the Taliban', Paper presented at the workshop on Transnationalism and Civil War. Download PDF.

Harpviken, Kristian Berg. 1997. 'Transcending nationalism: the emergence of non-state military formations in Afghanistan', Journal of Peace Research, 34(3), pages 271-287.

Human Terrain System. 2010. 'Kandahar Province Survey Report.' Download PDF.

Hyman, Anthony. 2002. 'Nationalism in Afghanistan', International Journal of Middle East Studies, Vol. 34, pp. 299-315.

Ibrahimi, Niamatullah. 2009. 'Divide and rule: State penetration in Hazarajat from monarchy to the Taliban', Working Paper No: 42 (series 2). Download PDF.

Ibrahimi, Niamatullah. 2009. 'At the sources of Factionalism and Civil War in Hazarajat', Working Paper No. 41 (series 2). Download PDF.

ICG. 2008. 'Taliban Propaganda: Winning the war of Words?', Asia Report N¹58.

Jackson, Paul. 2003. 'Warlords as alternative Forms of Governance', Small Wars \& Insurgencies, Vol. 14, No. 2.

Johnson, Thomas H. and Ahmad Waheed. 2011. 'Analyzing Taliban taranas (chants): an effective Afghan propaganda artifact', Small Wars \& Insurgencies, Vol. 22, No.1.

Johnson, Thomas H. and M. Chris Mason. 2008. 'No Sign until the Burst of Fire: Understanding the Pakistan-Afghanistan Frontier', International Security, Vol. 32, No. 4.

Johnson, Thomas H. 2007. 'On the Edge of the Big Muddy: The Taliban Resurgence in Afghanistan', China and Eurasia Forum Quarterly, Vol. 5, no. 2. Download PDF.

Johnson, Thomas H. and M. Chris Mason. 2007. 'Understanding the Taliban and Insurgency in Afghanistan', Orbis, Vol. 51, No. 1.

Johnson, Thomas. 2004. 'Ismail Khan, Herat and Iranian Influence', Strategic Insights, Vol. 3(7).

Jones, Seth G. 2008. 'Afghanistan's Growing Security Challenge', in State Building, Security, and Social Change in Afghanistan. Download PDF.

Jones, Seth G. 2008. 'The Rise of Afghanistan's Insurgency: State Failure and Jihad', International Security, Vol. 32, No. 4, pp. 7-40.

Judah, Tim. 2002. 'The Taliban Papers', Survival, Vol. 44, No. 1, pp. 69-80. 
Kemp, Robert. 2008. 'Religious Extremism and Militancy in the Pashtun Areas of Afghanistan and Pakistan', BC Journal, Special Volume / Fall 2008. Read online.

Kirk, Thomas. 2010. 'Afghanistan: Reconciliation Plans, Tribal Leaders and Civil Society', Small Wars Journal, Vol. 6, No. 12. Download PDF.

Kjaernet, H. and S. Torjesen. 2008. 'Insecurity and risk assessment of the situation in Afghanistan', Norwegian Institute for International Affairs. Download PDF.

Kongsgård, Håvard Wahl. 2011. 'The Genetics of Conflict: Low Level Interaction between Conflict Events.' Link to PDF.

Kouvo, Sari. 2009. 'Rule of Law Deficits as a Security Challenge: 'Touching the Surface", NATO Review, May 2009. Read online.

Lafraie, Najibullah. 2008. 'Resurgence of the Taliban insurgency in Afghanistan: How and why?', International Politics, Vol. 46, 1. Download PDF.

Lieven, Anatol. 2009. 'The war in Afghanistan: its background and future prospects', Conflict, Security \& Development, Vol. 9, Issue 3.

Livingston, lan S. et al. 2011. 'Afghanistan Index Tracking Variables of Reconstruction \& Security in Post-9/11 Afghanistan', Brookings. Download PDF.

Lyally, Jason, Kosuke Imaiz and Graeme Blair. 2011. 'Explaining Support for Combatants during Wartime: A Survey Experiment in Afghanistan', Download PDF.

MacKenzie, Jean. 2010. 'Militancy and Conflict in Helmand', New America Foundation. PDF.

Maley, William. 2011. 'Security and Instability in Afghanistan', in CSCAP Regional Security Outlook 2011. Edited by Brian L. Job. Council for Security Cooperation in the Asia Pacific.

Malkasian, Carter and Jerry Meyerle. 2009. 'How is Afghanistan Different from Al Anbar?', CNA Report. February 2009. Download PDF.

Mariet D'Souza, Shanthie. 2009. 'Talking to the Taliban: Will it Ensure 'Peace' in Afghanistan?', Strategic Analysis, Vol. 33, No 2.

Marshall, A. 2007. 'Managing Withdrawal: Afghanistan as the Forgotten Example in Attempting Conflict Resolution and State Reconstruction', Small Wars \& Insurgencies, Vol. 18, No. 1.

Marten, K. 2007. 'Warlordism in Comparative Perspective', International Security, Vol. 31(3). 
Merkova, Sonya et al. 2009. 'Conflict analysis: Chak and Sayedabad districts, Wardak province', Cooperation for Peace and Unity report, April 2009. Download PDF.

Miakhel, Shahmahmood and Noah Coburn. 2011. 'Promoting Stability and Resolving Provincial Disputes in Afghanistan', USIP. Download PDF.

Mikser, Sven. 2011. 'Transition in Afghanistan: Assessing the security effort', NATO. PDF.

Mishali-Ram, Meirav. 2008. 'Afghanistan: A Legacy of Violence? Internal and External Factors of the Enduring Violent Conflict', Comparative Studies of South Asia, Africa and the Middle East, Vol. 28, No. 3. Download PDF.

Nathan, Joanna. 2009. 'Reading the Taliban', in Antonio Giustozzi (ed.) Decoding the New Taliban: Insights from the Afghan Field. Hurst/Columbia University Press.

Nathan, Joanna. 2009. 'A Review of Reconciliation Efforts in Afghanistan', CTC Sentinel, Vol. 2, No. 8. Download PDF.

Niamatullah, Ibrahimi. 2006. 'The Failure of a Clerical Proto-State: Hazarajat, 1979-1984', Crisis States Working Paper, No. 6. Download PDF.

Nixon, Hamish and Caroline Hartzell. 2011. 'Beyond power sharing: institutional options for an Afghan peace process', USIP, PRIO, CMI. Download PDF.

Nixon, Hamish. 2011. 'Achieving Durable Peace: Afghan Perspectives on a Peace Process', PRIO. Download PDF.

Nojumi, Neamat. 2008. 'The Rise and Fall of the Taliban', in Robert D Crews and Amin Tarzi (editors). The Taliban and the Crisis of Afghanistan. Harvard University Press.

O'Hanlon, M. 2009. 'Towards Reconciliation in Afghanistan', The Washington Quarterly, Vol. 32, No. 2. Download PDF.

O'Loughlin, John, Frank D. W. Witmer, and Andrew M. Linke. 2010. 'The Afghanistan-Pakistan Wars, 2008-2009: Micro-geographies, Conflict Diffusion, and Clusters of Violence', Eurasian Geography and Economics, Vol. 51, No. 4.

Peters, Gretchen. 2010. 'Crime and Insurgency in the Tribal Areas of Afghanistan and Pakistan', Combating Terrorism Center. Download PDF.

Phillips, Andrew. 2009. 'The Anbar Awakening: Can It Be Exported to Afghanistan?', Security Challenges, Vol. 5, No. 3. Download PDF. 
Qazi, Shehzad H. 2011. 'The Neo-Taliban, Counterinsurgency, and the American Endgame in Afghanistan', Institute for Social Policy and Understanding. Download PDF.

Radnitz, Scott. 2004. 'Working with the Warlords: Designing an Ethnofederal System for Afghanistan', Regional and Federal Studies, Vol. 14, No. 4, Winter 2004, pp. 513-537.

Rahimi, Roohullah. 2008. 'Afghanistan: Exploring the Dynamics of Sociopolitical Strife and the Persistence of the Insurgency', Pearson Peacekeeping Centre. Download PDF.

Reuter, Christoph and Borhan Younus. 2009. 'The return of the Taliban in Andar District: Ghazni', in Antonio Giustozzi (ed.) Decoding the New Taliban: Insights from the Afghan Field. Hurst/Columbia University Press.

Roy, Olivier. 2002. 'Afghanistan: Internal Politics and Socio-Economic Dynamics and Groupings', WRITENET Paper, No. 14. Download PDF.

Roy, Olivier. 1992. 'Political elites in Afghanistan: rentier state building, rentier state wrecking', International Journal of Middle East Studies, 24.

Roy, Olivier. 1989. 'Afghanistan: war as a factor of entry into politics', Central Asian Survey, Volume 8, Issue 4, pp. 43-62.

Rubin. Barnett R. 2006. 'Peace Building and State-building in Afghanistan: Constructing Sovereignty for Whose Security?', Third World Quarterly, 27(1): 175-185.

Rubin, Barnett R. 2000. 'The Political Economy of War and Peace in Afghanistan', World Development, Vol. 28, No. 10, pp. 1789-1803.

Rubin, Barnett R. and Helena Malikyar. 2003. 'The Politics of Center-Periphery Relations in Afghanistan', Center on International Cooperation. Download PDF.

Ruttig, Thomas. 2011. 'Negotiations with the Taliban: History and Prospects for the Future', New America Foundation. Download PDF.

Ruttig, T. 2010. 'How Tribal Are the Taleban? Afghanistan's Largest Insurgent Movement between its Tribal Roots and Islamist Ideology', Afghanistan Analysts Network. Download PDF.

Ruttig, Thomas. 2010. 'The Ex-Taleban on the High Peace Council: A renewed role for the Khuddam ul-Furqan?', Afghanistan Analysts Network. Download PDF.

Ruttig, Thomas. 2011. 'Negotiations with the Taliban: History and Prospects for the Future,' New America Foundation. Download PDF. 
Ruttig, Thomas. 2009. 'The Other Side: Dimensions of the Afghan Insurgency: Causes, Actors and Approaches to 'Talks', Afghanistan Analysts Network. Download PDF.

Ruttig, Thomas. 2009. 'Loya Paktia's Insurgency: The Haqqani Network as an Autonomous Entity', in Antonio Giustozzi (ed.) Decoding the New Taliban: Insights from the Afghan Field. Hurst/Columbia University Press.

Ruttig, Thomas. 2006. 'Islamists, Leftists - and a Void in the Center: Afghanistan's Political Parties and where they came from, 1902-2006', Konrad Adenauer Stiftung. Download PDF.

Rzehak, Lutz. 2008. 'Remembering the Taliban', in Robert D Crews and Amin Tarzi (editors). The Taliban and the Crisis of Afghanistan. Cambridge, MA: Harvard University Press.

Saikal, Amin. 2009. 'The roots of the Afghan Conflict', in K. Foster (ed.), What Are We Doing in Afghanistan? Melbourne: Australian Scholarly Publishing.

Saikal, Amin. 2009. 'Afghanistan: The Unstable Strategic Bridge', Disarming Times. The Journal of Pax Christi Australia, Vol. 34, No. 4.

Saikal, Amin. 2000. 'The Role of Outside Actors in Afghanistan', Middle East Policy, Vol. 7(4).

Saikal, Amin. 1998. 'The Rabbani Government, 1992-1996', in William Maley (editor)

Fundamentalism Reborn? Afghanistan and the Taliban. New York University Press.

Saikal, Amin. 1998. 'Afghanistan's Ethnic Conflict', Survival, Vol. 40, No. 2.

Sajjad. Tazreena. 2010. 'Peace at all Costs? Reintegration and Reconciliation in Afghanistan', AREU. Download PDF.

Sakhi, Farishta. 2009. 'What is Needed to Enhance National Security?', Swedish Committee for Afghanistan Conference: Peace Building in Afghanistan. Download PDF.

Schetter, C. 2006. 'Geopolitics and the Afghan Territory', Geographische Rundschau International Edition, 2 (4): pages 20-26.

Schetter, Conrad. 2005. 'Ethnoscapes, National Territorialisation, and the Afghan War', Geopolitics, Vol. 10, pp. 50-75.

Schetter, C. and R. Glassner. 2009. 'The Changing Face of Warlordism in Afghanistan', in: H.-G. Ehrhart and C.C. Pentland (eds), The Afghanistan Challenge. Carleton University Press. PDF.

Schetter, C. and R. Glassner. 2009. 'Neither Functioning, nor failing of the State: Seeing Violence in Afghanistan from Local Perspectives', in S. Collmer (ed.), From Fragile State to Functioning State. Berlin. Download PDF. 
Schetter, Conrad, Rainer Glassner and Masood Karokhail. 2007. 'Beyond Warlordism: The local Security Architecture in Afghanistan', Internationale Politik und Gesellschaft 2: 136-153. PDF.

Schetter, Conrad, Rainer Glassner and Masood Karokhail. 2006. 'Understanding Local Violence: Security Arrangements in Kandahar, Kunduz and Paktia', Amu Darya Series. Paper No. 3. PDF.

Schmidt, Farhana. 2010. 'From Islamic Warriors to Drug Lords: The Evolution of the Taliban Insurgency', Mediterranean Quarterly, Vol. 21, No. 2.

Schutte, S. 2009. 'Informal (In)security in Urban Afghanistan', Iranian Studies, 42(3).

Senlis Council. 2006. 'Helmand at War: The Changing Nature of Insurgency in Southern Afghanistan and its Effects on the Future of the Country.' Download PDF.

Shahrani, M. Nazif. 2009. 'Afghanistan Since 1919: From Failed Modernization and Failed-State to a Post-Taliban Militia-State', in The Islamic world in the age of Western dominance. Volume 5 of The New Cambridge History of Islam. Francis Robinson, ed.

Shahrani, M. Nazif. 2008. 'Taliban and Talibanism in Historical Perspective', in R. D. Crews and A. Tarzi (eds). The Taliban and the Crisis of Afghanistan. Harvard University Press.

Shahrani, M. Nazif. 2002. 'War, Factionalism, and the State in Afghanistan', American Anthropologist, Vol. 104, No. 3. September 2002, pp. 715-722.

Shahrani, M. Nazif. 2001. 'Resisting the Taliban and Talibanism in Afghanistan: Legacies of a Century of Internal Colonialism and Cold War Politics in a Buffer State', Perceptions: Journal of International Affairs, 5(4). Download PDF.

Shahrani, M. Nazif. 1998. 'The Future of the State and the Structure of Community Governance in Afghanistan', in William Maley (editor) Fundamentalism Reborn? Afghanistan and the Taliban. New York: New York University Press.

Sharma, Prakhar. 2010. 'Local Contours of Security in Afghanistan', Stimson. PDF.

Shaw, Geoff. 2007. 'Afghanistan's Ghosts', Journal of Conflict Studies, Vol 27, No 1.

Sidky, H. 2007. 'War, Changing Patterns of Warfare, State Collapse, and Transnational Violence in Afghanistan: 1978-2001', Modern Asian Studies, Vol. 41, No. 4.

Simonsen, Sven Gunnar. 2004. 'Ethnicising Afghanistan?: inclusion and exclusion in post-Bonn institution building', Third World Quarterly, Vol. 25, No. 4. 
Singh, lesha. 2001. 'Exploring issues of violence within the recent context of the Hazarajat, Afghanistan', Central Asian Survey, 20:2, 195 - 227.

Smith, Graeme. 2009. 'What Kandahar's Taliban Say', in Antonio Giustozzi (ed.) Decoding the New Taliban: Insights from the Afghan Field. Hurst/Columbia University.

Snow, Chris et al. 2009. 'Conflict analysis: Farza and Kalakan districts, Kabul province', Cooperation for Peace and Unity, March 2009. Download PDF.

Steinberg, Guido and Nils Wormer. 2010. 'Escalation in the Kunduz Region: Who are the Insurgents in Northeastern Afghanistan?', SWP Comments, No. 33. PDF.

Stenersen, Anne. 2011. 'Al Qaeda's Foot Soldiers: A Study of the Biographies of Foreign Fighters Killed in Afghanistan and Pakistan Between 2002 and 2006', Studies in Conflict \& Terrorism, Vol. 34, No. 3.

Stenersen, Anne. 2010. 'The Taliban insurgency in Afghanistan - organization, leadership and worldview', Norwegian Defence Research Establishment. PDF.

Stenersen, Anne. 2010. 'Al-Qaeda's Allies: Explaining the Relationship Between Al-Qaeda and Various Factions of the Taliban After 2001', New America Found. PDF.

Stenersen, Anne. 2009. 'Are the Afghan Taliban Involved in International Terrorism?', CTC Sentinel, Vol. 2, No. 9. Download PDF.

Strick van Linschoten, Alex and Felix Kuehn. 2012. "Islamic, Independent, Perfect and Strong": Parsing the Taliban's Strategic Intentions, 2001-2011', AHRC. PDF.

Suhrke, Astri, et al. 2009. 'Conciliatory Approaches to the Insurgency in Afghanistan: An Overview', CMI Report. Download PDF.

Sullivan, Daniel P. 2007. 'Tinder, Spark, Oxygen, and Fuel: The Mysterious Rise of the Taliban', Journal of Peace Research, Vol. 44: pp. 93-108.

Swanström, Niklas L.P. and Svante E. Cornell. 2005. 'A Strategic Conflict Analysis of Afghanistan', Central Asia - Caucasus Institute. Download PDF.

Taliban. 2009. 'Taliban Rules and Regulations (2009).' [AKA 'Laheya']. PDF.

Taliban. 2009. 'A Book of Rules', The Islamic Emirate of Afghanistan (Quetta Shura). Translated by the NEFA Foundation. Download PDF.

Tariq, Mohammed Osman. 2008. 'Tribal Security System (Arbakai) in Southeast Afghanistan', Occasional Paper no.7, Crisis States Research Centre. Download PDF. 
Tarzi, Amin. 2008. 'The Neo-Taliban', in Robert D Crews and Amin Tarzi (editors). The Taliban and the Crisis of Afghanistan. Cambridge, MA: Harvard University Press.

Theros, Marika and lavor Rangelov. 2010. 'Field Notes from Afghanistan: Perceptions of Insecurity and Conflict Dynamics', London School of Economics. Download PDF.

Thomson, William. 2012. 'Criminal Organizations, Competitive Advantage and State Failure in Afghanistan', Small Wars Journal (January). Download PDF.

Thruelsen, Peter Dahl. 2010. 'The Taliban in southern Afghanistan: a localised insurgency with a local objective', Small Wars \& Insurgencies, Vol. 21, No. 2.

TLO. 2009. 'Three Years Later: A Socio-political Assessment of Uruzgan Province from 2006 to 2009. Tribal Liaison Office. Download PDF.

Trives, Sebastien. 2009. 'Loya Paktia's Insurgency: Roots of the Insurgency in the Southeast', in Antonio Giustozzi (ed.) Decoding the New Taliban: Insights from the Afghan Field. Hurst/Columbia University Press.

Trives, Sébastien. 2006. 'Afghanistan: Tackling the Insurgency, the Case of the Southeast', Politique étrangère, January.

Upadhyay, R. 2009. 'Taliban: Its Origin and the Historical Background', South Asia Analysis Group. Read Online.

Various Authors. 2009. Afghanistan, 1979-2009: In the Grip of Conflict. The Middle East Institute. Washington, DC. Download PDF.

Vigier, Corrina. 2009. 'Conflict Assessment: Afghanistan', American Friends Service Committee. Download PDF.

Waldman, Matt. 2010. 'The Sun in the Sky: The Relationship between Pakistan's ISI and Afghan Insurgents', Crisis States Research Centre. Download PDF.

Waldman, M. 2010. 'Navigating Negotiations in Afghanistan', USIP Peacebrief, No. 52. $\underline{\text { PDF. }}$

Waldman, Matt. 2010. 'Dangerous Liaisons with the Afghan Taliban: The Feasibility and Risks of Negotiations', United States Institute of Peace. Download PDF.

Waldman, Matt. 2010. 'Golden Surrender: The Risks, Challenges, and Implications of Reintegration in Afghanistan', Afghanistan Analysts Network. Download PDF. 
Waldman, Matt. 2008. 'Community Peacebuilding in Afghanistan: The Case for a National Strategy', Oxfam International. Download PDF.

Waldman, Matt and Thomas Ruttig 2011. 'Peace offerings: Theories of conflict resolution and their applicability to Afghanistan', Afghanistan Analysts Network. Download PDF.

Weinbaum, Marvin G. 2007. 'Security in Afghanistan', in Building State and Security in Afghanistan. Edited by Wolfgang Danspeckgruber. Woodrow Wilson School of Public and International Affairs. Download PDF.

Weinbaum, Marvin G. and Harder, Jonathan B. 2008. 'Pakistan's Afghan policies and their consequences', Contemporary South Asia, Vol. 16, No. 1, pp. 25-38.

Williams, Brian Glyn. 2011. 'On the Trail of the 'Lions of Islam': Foreign Fighters in Afghanistan and Pakistan, 1980-2010', Orbis, Vol. 55, No. 2.

Williams, Brian Glyn. 2010. 'Report from the Field. General Dostum and the Mazar i Sharif Campaign: New light on the role of Northern Alliance warlords in Operation Enduring Freedom', Small Wars and Insurgencies, Vol. 21, No. 4. Download PDF.

Williams, Brian Glyn. 2008. 'Talibanistan: History of a Transnational Terrorist Sanctuary', Civil Wars, Vol. 10, No 1, pp. 40-59.

Williams, Brian Glyn. 2008. 'Dostum: Afghanistan's Embattled Warlord', Terrorism Monitor, Vol. VI, Issue 8.

Witter, David, Anthony Bell, and Michael Whittaker. 2011. 'Reversing the Northeastern Insurgency', ISW Afghanistan Report No. 9. Download PDF.

Zeman, Phillip M. 2009. 'Tribalism and terror', Small Wars \& Insurgencies, Vol. 20(3).

Zyck, Steven. 2009. 'Former combatant reintegration and fragmentation in contemporary Afghanistan', Conflict, Security and Development, Vol. 9, No. 1. 


\section{Islam in Society, Politics and War}

\section{Books}

Abou Zahab, Mariam and Olivier Roy. 2004. Islamist Networks: The Afghan-Pakistan Connection. New York: Columbia University Press.

Canfield, Robert L. 1973. Faction and Conversion in a Plural Society: Religious Alignments in the Hindu Kush. Ann Arbor, MI: University of Michigan.

Centlivres, Pierre and Micheline Centlivres-Demont 2010. Afghanistan on the Threshold of the 21st Century: Three Essays on Culture and Society. Markus Wiener Publishers.

Haroon, Sana. 2007. Frontier of Faith: Islam in the Indo-Afghan Borderland. Columbia Uni Press.

Olesen, Asta. 1995. Islam and Politics in Afghanistan. Richmond, Surrey: Curzon.

\section{Articles, reports, and book chapters}

Ahmed, Faiz. 2007. 'Shari'a, Custom, and Statutory Law: Comparing State Approaches to Islamic Jurisprudence, Tribal Autonomy, and Legal Development in Afghanistan and Pakistan,' Global Jurist, Vol. 7, Issue 1.

Anderson, Jon W. 1984. 'How Afghans define themselves in relation to Islam', in M. Nazif Shahrani and Robert L. Canfield (editors), Revolution and Rebellions in Afghanistan:

Anthropological Perspectives. Berkeley, CA: University of California Press.

Anderson, Jon W. 1986. 'Popular mythologies and Subtle theologies: The Phenomenology of Muslim identity in Afghanistan', in Discourse and the Social Life of Meaning, edited by P. Chock and J. R. Wyman. Smithsonian Institute Press.

AREU. 2009. 'ACBAR Presentation Notes: Shiite Personal Status Law research.' PDF. 
Barfield, Thomas. 2005. 'An Islamic State is a State Run by Good Muslims: Religion as a Way of Life not an Ideology in Afghanistan,' in R. Hefner, ed. Remaking Muslim Politics: Pluralism, Contestation, Democratization. Princeton, NJ: Princeton University Press.

Barfield, Thomas. 2004. 'Radical Islam in an Afghan Context', in Political Transition in Afghanistan: The State, Islam and Civil Society. Asia Program Report, No 122. PDF.

Borchgrevink, Kaja and Kristian Berg Harpviken. 2010. 'Afghanistan's religious landscape: politicising the sacred', NOREF. Download PDF.

Borchgrevink, Kaja. 2010. 'Beyond Borders: Diversity and Transnational Links in Afghan Religious Education', PRIO paper. Download PDF.

Borchgrevink, Kaja and K. Harpviken. 2010. 'Teaching Religion, Taming Rebellion? Religious Education Reform in Afghanistan', PRIO Policy Brief, No. 7. PDF.

Borchgrevink, Kaja et al. 2007. 'Disconnected and Discounted? Religious actors and Civil Society in Post - 2001 Afghanistan', PRIO. Download PDF.

Borchgrevink Kaja. 2007. 'Religious Actors and Civil Society in Post-2001 Afghanistan', International Peace Research Institute, Oslo. Download PDF.

Broschk, Florian. 2011. 'Inciting the Believers to Fight: A closer look the rhetoric of the Afghan jihad', Afghanistan Analysts Network. Download PDF.

Burki, Shireen K. 2011. 'The Creeping Wahhabization in Pukhtunkhwa: The Road to 9/11', Comparative Strategy, Vol. 30, No. 2.

Canfield, Robert L. 1984. 'Islamic Sources of Resistance', Orbis 29(1): 57-71. 1984

Canfield, Robert L. 1976. 'Suffering as a religious imperative in Afghanistan', in The Realm of the Extra-human: Ideas and Actions. A. Bharati (ed.). The Hague: Mouton.

Caron, James M. 2007. 'Afghanistan Historiography and Pashtun Islam: Modernization Theory's Afterimage,' History Compass, 5/2 (2007): 314-329.

Christensen, Asger. 1988. 'When Muslim identity has different meanings: Religion and politics in contemporary Afghanistan', in Islam: State and Society. Klaus Ferdinand and Mehdi Mozaffari (editors). London: Curzon Press.

Cornell, Svante E. 2005. “Taliban Afghanistan: A True Islamic State?” In The Limits of Culture: Islam and Foreign Policy, ed. Brenda Shaffer. Cambridge: MIT Press.

Dupree, L. 1979. 'Further Notes on Taqiyya: Afghanistan', JAOS, Vol. 99, pp. 680-82. 
Dupree, Louis. 1976. 'Saint cults in Afghanistan', South Asia Series / American Universities Field Staff. Vol. 20(1), p. 1-26.

Edwards, David B. 1986. 'The evolution of Shi'i political dissent in Afghanistan', in J. Cole and N. Keddie (editors), Shi'ism and Social Protest. Yale University Press.

Edwards, David B. 1993. 'Summoning Muslims: print, politics, and religious ideology in Afghanistan', Journal of Asian Studies, 52(3).

Emadi, Hafizullah. 2000. 'Praxis of taqiyya: perseverance of Pashaye Ismaili enclave, Nangarhar, Afghanistan', Central Asian Survey, 19(2), pp. 253-264.

Emadi, Hafizullah. 1993. 'Minority group politics: the role of Ismailis in Afghanistan's politics', Central Asian Survey, 12(3), pages 379-392.

Freeman, Christopher P. 2002. 'Dissonant Discourse: Forging Islamist States through Secular Models: The Case of Afghanistan', Cambridge Review of International Affairs, Vol. 15, No. 3.

Ghani, Ashraf. 1983. 'Disputes in a Court of Sharia, Kunar Valley, Afghanistan, 1885-1890', International Journal of Middle East Studies, Vol. 15, No. 3.

Ghani, Ashraf. 1987. 'Afghanistan: Islam and Counterrevolutionary Movements', in Islam in Asia: Religion, Politics, and Society. J. Esposito (ed.). Oxford University Press.

Ghani, Ashraf. (1978) 'Islam and state-building in a tribal society-Afghanistan: 1880-1901', Modern Asian Studies, Vol 12, No 2, pp 269-284.

Green, Nile. 2008. 'Tribe, Diaspora, and Sainthood in Afghan History', The Journal of Asian Studies, Vol. 67, No. 1, pp. 171-211.

Haqqani, Hussein. 2007. 'Afghanistan's Islamist Groups' in Current Trends in Islamist Ideology. Edited by Hussain Haqqani et al. Volume 5. Hudson Institute. Download PDF.

Kamali, Mohammad Hashem. 2005. 'Islam and its Sharica in the Afghan Constitution 2004 with Special Reference to Personal Law', in The Shari'a in the Constitutions of Afghanistan, Iran and Egypt. Edited by Nadjma Yassari. Tubingen: Mohr Siebeck.

Koepke, Bruce. 2002. The impact of political Islam on cultural practices in Badakhshan, Afghanistan, during the Taliban era. Thesis (Ph.D.)--Australian National University.

Kopecky, Lucas-Michael. 1982. 'The Imami Sayyed of the Hazarajat: the maintenance of their elite position', Folk, Vol. 24, pp. 89-110. 
Lau, Martin. 2010. 'Islamic law and the Afghan legal system', LSE Research Online. PDF.

Lizzio, Kenneth. 2006. 'The Naqshbandi/Saifiyya Battle for Islamic Tradition', The Muslim World, Vol. 96.

Malikyar, H. 1997. 'Development of family law in Afghanistan: The roles of the Hanafi Madhhab, customary practices and power politics', Central Asian Survey, Vol.16, No. 3.

Marsden, Magnus. 2009. 'Talking the Talk: Debating Debate in Northern Afghanistan', Anthropology Today, Vol. 25 No. 2.

Mendoza, Kristin (n.d.) 'Islam and Islamism in Afghanistan', Afghan Legal History Project, Harvard Law School. Download PDF.

Mock, John. 2011. 'Shrine Traditions of Wakhan Afghanistan', Journal of Persianate Studies, Volume 4, Number 2.

Naby, Eden. 1994. 'The Changing role of Islam as a Unifying Force in Afghanistan', in The Politics of Social transformation in Afghanistan, Iran, and Pakistan. Ali Banuazizi and Myron Weiner (editors). NY: Syracuse University Press.

Niyozov, Sarfaroz. 2003. 'Evolution of the Shi'a Ismaili Tradition in Central Asia', The Institute of Ismaili Studies. Download PDF.

NPWJ. 2009. 'Afghanistan's Shi'a Personal Status Law', No Peace Without Justice. PDF.

Oates, Lauryn. 2009. 'A Closer Look: The Policy and Law-making Process Behind the Shiite Personal Status Law', Afghanistan Research and Evaluation Unit. Download PDF.

Rahmani, Ahmad Idrees. 2006. 'The Role of Religious Institutions in Community Governance Affairs: How are Communities Governed Beyond the District Level?', CPS International Policy Fellowship Program. Download PDF.

Rahmani, Ahmad Idrees. 2006. 'The Role of Religious Leaders in the Provision of Local Services in Afghanistan', CPS International Policy Fellowship Program. Download PDF.

Roy, Olivier. 1998. 'Has Islamism a Future in Afghanistan?', in William Maley (editor) Fundamentalism Reborn? Afghanistan and the Taliban. New York University Press.

Roy, Olivier. 1994. 'Afghanistan: Jihad and Traditional Society', in The Failure of Political Islam. Cambridge: Cambridge University Press.

Roy, Olivier. 1993. 'Afghanistan: An Islamic war of resistance', in Fundamentalisms and the state. Martin Marty and R. S. Appleby (eds). Chicago: University of Chicago Press. 
Roy, Olivier. 1983. 'Sufism in the Afghan resistance', Central Asian Survey, 2(4).

Rubin, Barnett R. 1997. 'Arab Islamists in Afghanistan', in Political Islam: Revolution, Radicalism or Reform? John Esposito (editor). Boulder, CO: Lynne Rienner Press.

Schmeidl, Susanne. 2007. 'Collaborating with Religious Actors in Afghanistan', in Role and Meaning of Religion and Spirituality in Development-Cooperation. Berne: Swiss Agency for Development Cooperation.

Seleny, Anna. 2007. 'Islam and the Transformative Power of Tradition', in Building State and Security in Afghanistan. Edited by Wolfgang Danspeckgruber. Woodrow Wilson School of Public and International Affairs. Download PDF.

Shahrani, M. Nazif. 1991. 'Local Knowledge of Islam and Social Discourse in Afghanistan and Turkistan in the Modern Period', In Turko-Persia in Historical-Perspective, edited by Robert L. Canfield. Cambridge University Press.

Shalinsky, Audrey C. 1990. 'The significance of Islam in pre-1978 Northern Afghanistan: An Urban Uzbek example', Central Asian Survey, Volume 9, Issue 4, pp. 99 - 108.

Shalinski, Audrey C. 1982. 'Islam and Ethnicity: The Northern Afghan Perspective', Central Asian Survey, Vol. 1, No. 2/3 (November 1982), pp. 71-84.

Sharma, Prakhar. 2009. 'Role of Religion in Afghan Politics: Evolution and Key Trends', in Renewal and Resistance in the Muslim World. Stimson Center. Download PDF.

Sidky, M. H. 1990. 'Malang, Sufis, and Mystics: An Ethnographic and Historical Study of Shamanism in Afghanistan', Asian Folklore Studies, Volume 49, pp. 275-301.

Tariq, Mohammed Osman et al. 2011. 'Building Trust and Institutions - Religious InstitutionBuilding in Afghanistan: An Exploration', PRIO Policy Brief 2. PDF.

Tariq, Mohammed Osman. 2011. 'Religious Institution Building in Afghanistan: An Exploration', PRIO Paper. Download PDF.

Tarzi, Amin and Helena Malikyar. 2000. 'The Jilani Family of Afghanistan', Journal of the History of Sufism, Vol. 1, No. 2.

USAID. 2009. 'Shiite Personal Status Law: English Translation', USAID. Downoad PDF.

Wardak, Miwais, Idrees Zaman and Kanishka Nawabi. 2007. 'The Role and Functions of Religious Civil Society in Afghanistan Case Studies From Sayedabad \& Kunduz', Research and Advocacy Department Cooperation for Peace And Unity. Download PDF. 


\section{Military: Operations, Civil-Military Relations, and COIN}

\section{Books}

Giustozzi, Antonio. 2008. Koran, Kalashnikov and Laptop: The Neo-Taliban Insurgency in Afghanistan. New York: Columbia University Press.

Grau, Lester W. and Dodge Billingsley. 2011. Operation Anaconda: America's First Major Battle in Afghanistan. University Press of Kansas.

Grau, Lester W. (editor) 2003. The Bear Went Over the Mountain: Soviet Combat Tactics in Afghanistan. Routledge.

Gress, Michael A. and Lester W. Grau (eds), Russian General Staff. 2002. The Soviet-Afghan War: How a Superpower Fought and Lost. University Press of Kansas.

Jalali, Ahmed Ali and Lester W. Grau. 2002. Afghan Guerilla Warfare. Osprey.

Johnson, Rob. 2011. The Afghan Way of War. Hurst/Columbia.

Ledwidge, Frank. 2011. Losing Small Wars: British Military Failure in Iraq and Afghanistan. Yale University Press.

Maloney, Sean M. 2009. Confronting the Chaos: A Rogue Military Historian Returns to Afghanistan. Naval Institute Press.

McMichael, Scott R. 1991. Stumbling Bear: Soviet Military Performance in Afghanistan. Brassey's, London.

Porter, Patrick. 2009. Military Orientalism: Eastern War Through Western Eyes. Hurst (UK), Columbia University Press (US).

Rietjens, S.J.H. 2008. Civil-Military Cooperation in Response to a Complex Emergency: Just Another Drill? Netherlands Defence Academy.

Rothstein, H.S. 2006. Afghanistan and the Troubled Future of Unconventional Warfare. Monterey, CA: Naval Institute Press. 
Schlosser, Nicholas and James Caiella (editors). 2011. Counterinsurgency Leadership in Afghanistan, Iraq, and Beyond. Marine Corps University Press. Download PDF.

Tamas, Andy. 2009. Warriors and Nation Builders: Development and the Military in Afghanistan. Kingston: Canadian Defence Academy Press. Download PDF.

Wright, Donald P. et al. 2010. A Different Kind of War: The United States Army in OPRATION ENDURING FREEDOM, October 2001 - September 2005. Fort Leavenworth, KS: Combat Studies Institute Press. Download PDF.

\section{Articles, Reports and Book Chapters}

Abbasi, Rizwana. 2008. 'Ethics of the war on terror - can the war in Afghanistan be won under the present rules of engagement?', Paper at University of Leicester seminar. PDF.

Abbaszadeh, Nima, et al. 2008. 'Provincial Reconstruction Teams: Lessons and Recommendations,' Princeton University Woodrow Wilson School. Download PDF.

Adair, Jason T. 2008. 'Learning on the run: company level counter-insurgency in Afghanistan', Canadian Army Journal, Vol. 10, No. 4. Download PDF.

Afsar, Shahid, Chris Samples, and Thomas Wood. 2008. 'The Taliban: An Organizational Analysis', Military Review, May-June 2008. Download PDF.

Ahmad, Irfan. 2009. Role of Airpower for Counterinsurgency in Afghanistan and FATA (Federally Administered Tribal Areas). NPS master's thesis. Download PDF.

Ali, Imtaz. 2008. 'Preparing the Mujahidin: The Taliban's Military Field Manual', CTC Sentinel, Vol. 1, Issue 10. Download PDF.

Almantas Leika. 2007. 'Operational and Strategic Lessons Learned from Running a PRT', $2^{\text {nd }}$ Annual Baltic Conference on Defence (ABC/D). Download PDF.

Amend, Kurt. 2008. 'Counterinsurgency Principles for the Diplomat', Small Wars Journal. PDF.

American Anthropological Association. 2009. 'Afghanistan: The Army's Human Terrain System Proof of Concept Program'. Download PDF.

Armstrong, Bradley J. 2003. Rebuilding Afghanistan: counterinsurgency and reconstruction in Operation Enduring Freedom. NPS Thesis (M.S). Download PDF. 
ARRC. 2009. 'My Cousin's Enemy is My Friend: A Study of Pashtun "Tribes" in Afghanistan', Afghanistan Research Reachback Center White Paper. TRADOC G2 Human Terrain System. United States Army. Fort Leavenworth, KS. Download PDF

Azarbaijani-Moghaddam, Sippi et al. 2008. 'Afghan Hearts, Afghan Minds: Exploring Afghan perceptions of civil-military relations', ENNA/BAAG. Download PDF.

BAAG/ENNA. 2008. 'Aid and Civil-Military Relations in Afghanistan BAAG and ENNA policy briefing. Download PDF.

Barno, David W. 2007. 'Fighting "The Other War:" Counterinsurgency Strategy in Afghanistan, 2003-2005', Military Review, Sept-Oct 2007. Download PDF.

Barrett, Richard. 2010. 'Boldness Be My Friend: Why the High Risk Plan is Often the Safest (and the Most Successful)', Australian Army Journal, Vol. VII, No. 3. PDF.

Basso, John A. 2004 America's last battles: organizing brigades to win the peace 14 lessons from East Timor, Afghanistan, and Iraq. U.S. Army CGSC. Download PDF.

Bebber, Robert J. 2009. 'Developing an IO Environmental Assessment in Khost Province: Information Operations at PRT Khost in 2008', Small Wars Journal, February 2009. PDF.

Behr, Timo. 2011. 'Germany and Regional Command-North: ISAF's Weakest Link?', in Statebuilding in Afghanistan: Multinational Contributions to Reconstruction. Edited by Nik Hynek and Péter Marton. Routledge.

Bell, Kevin. 2009. 'Pulling Teeth: An Infantry Platoon Leader's Perspective on a Year in Afghanistan', Army Magazine, May 2009.

Betz, David and Anthony Cormack. 2009. 'Wars Amongst the People: Iraq, Afghanistan and British Strategy', Orbis, Spring 2009, Volume 53, Number 2.

Betz, David. 2008. 'The virtual dimension of contemporary insurgency', Small Wars \& Insurgencies, Vol. 19, No. 4.

Bird, Sheila. 2009. 'IEDs and Military Fatalities in Iraq and Afghanistan', The RUSI Journal, Volume 154, Issue 4.

Blatt, Darren J., Eric Long, Brian Mulhern and Michael Ploskunak. 2009. 'Tribal Engagement in Afghanistan', Special Warfare, Volume 22, Issue 1. Download PDF.

Blatt, Darin J. and Glenn Bollinger. 2009. 'Out of the Box: Training Combat Adviser for Afghanistan', Special Warfare, Vol. 22, No. 3. Download PDF. 
Bluesteen, Christopher. 2009. 'Combat Advising: Three Challenges We Must Overcome to Succeed in Afghanistan', Small Wars Journal, April. Download PDF.

Bolduc, C. and Captain J. Vachon. 2010. 'Making Strides at the Heart of the Insurgency', Canadian Army Journal, Volume 13, No. 2. Download PDF.

Bolduc, Donald C. 2009. 'Organizing Counterinsurgency Operations in Afghanistan', Small Wars Journal, August 2009. Download PDF.

Booth, Brad. 2008. 'Winning in Afghanistan: a NATO Operational Design', US Army War College. Download PDF.

Bowen, D. 2010. 'Combatants in Afghanistan: What's in a Name?', Canadian Army Journal, Volume 13, No. 2. Download PDF.

Bowen, Dominic. 2010. 'Combatants in Afghanistan: What's in a Name?', Australian Army Journal, Vol. VII, No. 3. Download PDF.

Brandt, Ben. 2011. 'The Taliban's Conduct of Intelligence and Counterintelligence', CTC Sentinel, Vol. 4, No. 6. Download PDF.

Bue, Kara L. and John A. Gastright. 2009. 'The Debate over Taliban Reconciliation', CTC Sentinel, Vol. 2, Issue 2. Download PDF.

Bristol, N. 2006. 'Military Incursions into Aid Work Anger Humanitarian Groups', The Lancet, Volume 367, Issue 9508 (February 4, 2006): pages 384-386.

Brouns, T. 2009. 'Exploiting Insurgent Violence', Military Review, July-August. PDF.

Buntak, Antonija \& Robert Mikac. 2011. 'The Political Dimension of Counterinsurgency Operations: A Comparison of Two Counterinsurgency Operations in Afghanistan', Contemporary Issues, Vol. 4, No. 1.

Cadieu, Trevor. 2008. 'Canadian Armour in Afghanistan', Canadian Army Journal, Vol. 10.4 (Winter 2008), pp. 5-25. Download PDF.

Caldwell, William B. and Derek S. Reveron. 2011. 'Surging Security Force Assistance in Afghanistan', Military Review (November-December). Download PDF.

Campbell, Jason et al. 2009. 'Assessing Counterinsurgency and Stabilization Missions', Foreign Policy at Brookings Policy Paper No. 14. Download PDF.

Cassidy, Robert M. 2003. 'Russia in Afghanistan and Chechnya: military strategic culture and the paradoxes of asymmetric conflict', Strategic Studies Institute. Download PDF. 
CENTCOM Public Affairs. 2009. 'US Central Command Investigation into Civilian Casualties in Farah Province.' Download PDF.

Cerami, J. and J. Boggs. 2007. 'The Interagency and Counterinsurgency Warfare: Stability, Security, Transition, and Reconstruction Roles', SIS. Download PDF.

Chandrasekaran, Rajiv. 2011. 'Is NATO's Counterinsurgency Strategy Working in Afghanistan? A Case Study', Centre for International Policy Studies. Download PDF.

Chaudhuri, Rudra and Theo Farrell. 2011. 'Campaign disconnect: operational progress and strategic obstacles in Afghanistan, 2009-2011', International Affairs, Vol. 87, No. 2.

Chin, Warren. 2010. 'Colonial Warfare in a Post-Colonial State: British Military Operations in Helmand Province, Afghanistan', Defence Studies, Vol. 10, No. 1.

Chin, Warren. 2007. 'British Counter-Insurgency in Afghanistan', Defense \& Security Analysis, Vol. 23, No. 2, pp. 201-225.

Choharis, Peter Charles and James A. Gavrilis. 2010. 'Counterinsurgency 3.0', Parameters, Spring 2010. Download PDF.

Clark, Kate. 2011. 'The Takhar attack: Targeted killings and the parallel worlds of US intelligence and Afghanistan', Afghanistan Analysts Network. Download PDF.

Clukey, David S. 2010. 'A District Approach in Afghanistan?', Small Wars Journal, April. $\underline{\text { PDF. }}$

Coffey, Luke. 2009. 'Detainee Operations in Counterinsurgency Operations Lessons from Afghanistan 2005-2006', Small Wars Journal, September 2009. PDF.

Collins, J. 2009. 'Afghanistan: The Path to Victory', Joint Force Quarterly, 54. PDF.

Collins, J. 2007. 'The Perils of Planning: Lessons from Afghanistan and Iraq', in The Interagency and Counterinsurgency Warfare: Stability, Security, Transition, and Reconstruction Roles. Ed. by J. Cerami and J. Boggs. Download PDF.

Condra, Luke N. et al. 2010. 'The Effect of Civilian Casualties in Afghanistan and Iraq', NBER working paper. Download PDF.

Connable, Ben. 2009. 'All our eggs in one basket: how the Human Terrain System is undermining sustainable military cultural competence', Military Review, Mar.-Apr. PDF.

Cordesman, A. 2009. 'The Air War in Afghanistan: The Broader Issue', CSIS. PDF. 
Cordesman, Anthony H. 2009. "'Shape, Clear, Hold, and Build:" The Uncertain Metrics of the Afghan War', CSIS. Download PDF.

Corn, Tony. 2009. 'Toward a Kilcullen-Biden Plan? Bounding Counterinsurgency in Afghanistan', Small Wars Journal, October 2009. Download PDF.

Cornish, S. and M. Glad. 2008. 'Civil-military relations: no room for humanitarianism in comprehensive approaches', CARE International. Download PDF.

Cornish, Stephen and Marit Glad. 2009. 'Civil-Military Relations: No Room for Humanitarianism in Comprehensive Approaches', Norwegian Atlantic Committee. PDF.

Cornish, P. 2007. 'No room for humanitarianism in 3D policies: have forcible humanitarian interventions and integrated approaches lost their way?', Centre for Military and Strategic Studies, University of Calgary. Download PDF.

Cornish, S. and M. Glad. 2008. 'Civil-military relations: no room for humanitarianism in comprehensive approaches', CARE International. Download PDF.

Coss, Michael A. 2006. 'Operation Mountain Lion: CJTF-76 in Afghanistan Spring 2006,' Military Review, January-February 2008. Download PDF.

Cox, David. 1991. Soviet counterinsurgency doctrine and strategy in Afghanistan: an operational assessment of the campaign. Thesis (Ph. D.)--George Washington University.

Cox, Joseph L. 2006. 'Information Operations in Operations Enduring Freedom and Iraqi Freedom: What Went Wrong?', SAMS Monograph. Download PDF.

Crow, Trampes C. 2010. 'Unfocused Energy: A Strategic Approach to U.S. Communications in Afghanistan', SAMS Monograph. Link to PDF.

Crumpton, Henry. 2005. 'Intelligence and War: Afghanistan 2001-2', in Transforming U.S. Intelligence. Edited by E. Sims and Burton Gelber. Washington: Georgetown University Press.

Dadkhah, Lara M. 2008. 'Close Air Support and Civilian Casualties in Afghanistan', Small Wars Journal, December 2008. Download PDF.

Dale, Catherine. 2011. 'War in Afghanistan: Strategy, Operations, and Issues for Congress', Congressional Research Service. Download PDF.

Danovic, Neno. 2012. 'You Can't Play Chess When the Taliban is Playing Poker', Small Wars Journal (January). Download PDF. 
Darling, Paul. 2011. 'The Five Fights of the Surkhagan and the Future of ISAF', Military Review, July-August. Download PDF.

Davis, Mark G. 2004. Operation Anaconda command and confusion in Joint Warfare. Dissertation thesis--School of Advanced Air and Space Studies, Air University.

Dehnert, P.A. 2010. 'Size Matters: Turning to Small Teams to Succeed at Counterinsurgency', Australian Army Journal, Vol. VII, No. 3. Download PDF.

Depart. of Defense. 2009. 'Afghanistan Security Forces Fund Phase III-U.S. Army Corps of Engineers Real Property Accountability', Inspector General Dept. of Defense. PDF.

Department of Defense. 2008. 'Assessment of Arms, Ammunition, and Explosives Control and Accountability; Security Assistance; and Sustainment for the Afghan National Security Forces', US Department of Defense. Downoad PDF.

Department of Defense. 2007. 'Strategic Communication Plan for Afghanistan.' PDF.

Dessaso, Christopher D. 2010. 'Toward Development of Afghanistan National Stability: Analyses in Historical, Military, and Cultural Contexts', SAMS Monograph. Link to PDF.

Dietz, A. Steven. 2011. 'Countering the effects of IED systems in Afghanistan: an integral approach', Small Wars \& Insurgencies, Vol. 22, No. 2.

Dimitriu, George and Beatrice de Graaf. 2010. 'The Dutch COIN approach: three years in Uruzgan, 2006-2009', Small Wars \& Insurgencies, Vol. 21, No. 3.

Dobbins, James. 2009. 'Counterinsurgency in Afghanistan', Testimony presented before the Senate Armed Services Committee on February 26, 2009. Download PDF.

Donahue, Patrick and Michael Fenzel. 2008. 'Combating a Modern Insurgency: Combined Task Force Devil in Afghanistan', Military Review, March-April 2008. PDF.

Donkersloot, Eric et al. 2011. 'Going Dutch: Counternarcotics Activities in the Afghan Province of Uruzgan', Military Review (September-October). Download PDF.

Doohovskoy, Andrei A. 2009. Soviet Counterinsurgency in the Soviet Afghan War Revisited: Analyzing the Effective Aspects of the Counterinsurgency Effort. MA thesis, Harvard University.

Downey, Robert A. 2008. 'How Should the U.S. Execute a Surge in Afghanistan?', Small Wars Journal, November 2008. Download PDF.

Dressler, Jeffrey. 2009. 'Securing Helmand: Understanding and Responding to the Enemy', Institute for the Study of War. Afghanistan Report \#2. Download PDF. 
Dubik, Kames M. 2009. 'Accelerating Combat Power in Afghanistan', Best Practices in Counterinsurgency, Report \#2. Download PDF.

DuPee, Matthew C. 2008. 'Badghis Province: examining the Taliban's Northwestern Campaign', The Culture and Conflict Review, Vol. 2, No. 5. Download PDF.

Dyke, John R. and John R. Crisafulli. 2006. 'Unconventional Counter-Insurgency in Afghanistan', Thesis, Naval Postgraduate School. Monterey, CA. Download PDF.

Edwards, David B. 2010. 'Counterinsurgency as a Cultural System', Small Wars Journal, December 2010. Download PDF.

Egnell, Robert. 2010. 'Winning 'Hearts and Minds'? A Critical Analysis of Counter-Insurgency Operations in Afghanistan', Civil Wars, Vol. 12, No. 3.

Egnell, Robert. 2011. 'Lessons from Helmand, Afghanistan: what now for British counterinsurgency?', International Affairs, Volume 87, Issue 2.

Ehrhart, Thomas P. 2009. 'Increasing Small Arms Lethality in Afghanistan: Taking Back the Infantry Half-Kilometer', SAMS Monograph. Link to PDF.

Eikenberry, Karl W. and Stanley H. McChrystal. 2009. 'United States Government Integrated Civilian - Military Campaign Plan for Support to Afghanistan', U.S. Chief of Mission and the Commander of U.S. Forces-Afghanistan. Download PDF.

Erwin, Michael. 2008. 'Key Factors for the Recent Growth of the Afghan Insurgency', CTC Sentinel, Vol. 1, Issue 9. Download PDF.

Exum, Andrew W. et al. 2009. 'Triage: The Next Twelve Months in Afghanistan and Pakistan', CNAS Report. Download PDF.

Fairweather, Clive. 2009. 'Afghanistan: Statistics of War; Helicopters, bombs and strategies', Significance, Volume 6, Issue 4.

Farrell, Theo and Stuart Gordon. 2009. 'COIN Machine: The British Military in Afghanistan', Orbis, Vol. 53, Issue 4.

Fenzel, Michael. 2010. 'The Maneuver Company in Afghanistan: Establishing Counterinsurgency Priorities at the District Level', Military Review, March-April. PDF.

Ferris, John. 2006. 'Invading Afghanistan, 1838-2006: Politics and Pacification', Journal of Military and Strategic Studies, Vol. 9, Issue 1. Download PDF. 
Fick, Nathaniel C. and John A. Nagl. 2009. 'Counterinsurgency Field Manual: Afghanistan Edition', Foreign Policy, Jan./Feb. Read online.

Finel, Bernard I. 2010. 'Planning a Military Campaign to Support Negotiations in Afghanistan', Small Wars Journal, Vol. 6, No. 10. Download PDF.

Fitzgerald, Ronald J. 2010. 'The Canadian Strategic Advisory Team to Afghanistan: A Possible Model for a Multinational Whole of Government Approach to Defeating an Insurgency', SAMS Monograph. Link to PDF.

Flynn, Michael T. 2010. 'Fixing Intel: A Blueprint for Making Intelligence Relevant in Afghanistan', Center for a New American Security. Download PDF.

Foust, Joshua. 2009. 'What Really Happened in the Tagab Valley? A Response to Second Lieutenant James Parker', Small Wars Journal, September 2009. Download PDF.

Foxley, Tim. 2007. 'The Taliban's propaganda activities: how well is the Afghan insurgency communicating and what is it saying?', SIPRI Project Paper. Download PDF.

Fraser, Andrew. 2009 'Deadly Ends: Canada, NATO and Suicide as a Weapon of War in Modern Afghanistan', Canadian Army Journal, Vol. 12, No. 2. Download PDF.

French, Nils N. 2008. 'The Sarposa Prison Break', Canadian Army Journal, Vol. 11, No. 2. Download PDF.

French, Nils N. 2008. 'Learning from the Seven Soviet Wars: Lessons for Canada in Afghanistan', Canadian Army Journal, Vol. 10.4, pp. 36-47. Download PDF.

Frerks, G. et al. 2006. 'Principles and pragmatism: civil-military action in Afghanistan and Liberia', Cordaid. Download PDF.

Frewen, John. 2008.'Contested Nation-Building: The Challenge of Countering Insurgency in Afghanistan in 2007', Australian Army Journal, Vol. 5, Number 1. PDF.

Galli, Thomas. 2008. 'The Narcotics Counterinsurgency Dilemma', SAMS Monograph. PDF.

Gauster, Markus. 2008. 'Provincial Reconstruction Teams in Afghanistan', Marshall European Center for Security Studies. Occasional Paper \#16 (January 2008). PDF.

Gauthier, Michel. 2009. 'Canadian Forces in Afghanistan - Then, Now and Beyond', On Track, Vol. 14, No. 1. 
GAO. 2009. 'Military Operations: Actions Needed to Improve Oversight and Interagency Coordination for the Commander's Emergency Response Program in Afghanistan', Government Accountability Office. Download PDF.

Gentile, Gian P. 2009. 'Gaining the Initiative in Afghanistan', Small Wars Journal, September 2009. Download PDF.

Gezari, Vanessa. 2010. 'Rough Terrain: The Human Terrain System in Afghanistan', in The Afghanistan-Pakistan Theater: Militant Islam, Security \& Stability. Edited by Edited by Daveed Gartenstein-Ross \& Clifford D. May. Washington: FDD Press. PDF.

Gibbs, David. 1986. 'The Peasant as Counter-Revolutionary: The Rural Origins of the Afghan Insurgency', Studies in Comparative International Development, Vol. 21(1).

Gibson, John G. 2008. 'After Action Report: Nuanced Diplomacy in Zerok, Afghanistan', CTC Sentinel, Vol 1, Issue 8. Download PDF.

Glatz, Rainer. 2011. 'ISAF lessons learned: A German perspective', PRISM 2, No. 2 PDF.

Glenn, Russell W. and S. Jamie Gayton. 2008. 'Intelligence Operations and Metrics in Iraq and Afghanistan', RAND. Download PDF.

Goepner, Erik W. 2012. 'Battered Spouse Syndrome: How to Better Understand Afghan Behavior', Military Review (January-February). Download PDF.

Golinghorst, K. 2010. 'Mapping the Human Terrain in Afghanistan', SAMS Monograph. PDF.

Grau, Lester. 2009. 'The Soviet-Afghan War: A Superpower Mired in the Mountains', in Conflict and Insurgency in the Contemporary Middle East. Barry Rubin (ed). Routledge.

Grau, Lester W. 2007. 'Breaking Contact Without Leaving Chaos: The Soviet Withdrawal from Afghanistan', The Journal of Slavic Military Studies, Vol. 20(2).

Grau, Lester W. 1999. 'The Soviet-Afghan War: A Superpower Mired In The Mountains', Journal of Slavic Military Studies, Vol. 17, Issue 1.

Grasso, Valerie Bailey. 2009. 'Defense Logistical Support Contracts in Iraq and Afghanistan: Issues for Congress', CRS Report for Congress. Download PDF.

Green, Daniel R. 2011. 'Defeating the Taliban's Shadow Government: Winning the Population through Synchronised Governance, Development and Security Efforts', Australian Army Journal, Volume VIII, Number 1. Download PDF. 
Green, Dan. 2009. 'Going Tribal: Enlisting Afghanistan's Tribes', Small Wars Journal, August 2009. Download PDF.

Griffin, Stuart. 2011. 'Iraq, Afghanistan and the future of British military doctrine: from counterinsurgency to Stabilization', International Affairs, Vol. 87, Issue 2.

Groh, Ty L. 2006. 'Ungoverned Spaces: the Challenges of Governing Tribal Societies', Naval Postgraduate School Thesis. Monterey, California (June 2006). Download PDF.

Hack, Karl. 2009. 'Extracting counterinsurgency lessons: The Malayan Emergency and Afghanistan', History on Rusi.org. Download PDF.

Hall, Michael T. and Stanley McChrystal. 2009. 'COMISAF/USFOR-A Counterinsurgency (COIN) Training Guidance', NATO/ISAF. Download PDF.

Hammes, T.X. et al. 2009. 'Afghanistan: Connecting Assumptions and Strategy', Proceedings, November 2009.

Hastert, Paul L. 2005 'Operation Anaconda: Perception Meets Reality in the Hills of Afghanistan', Studies in Conflict and Terrorism, Vol. 28, No. 1.

Hastings, Michael D. 2005. Integration of conventional forces and special operations forces. Thesis (MMAS)-U.S. Command and General Staff College (CGSC). PDF.

Håvoll, Harald. 2008. 'COIN Revisited: Lessons of the classical literature on counterinsurgery and its applicability to the Afghan hybrid insurgency', NUPI Report. Download PDF.

Hawkins, Jon. 2010. 'Assessing Afghanistan against Aden and Oman: A Euphemism for Capitulation or the Seeds of Success?', Australian Army Journal, Volume VII(1). PDF.

Hoadley, Stephen. 2011. 'The New Zealand PRT Experience in Bamyan Province: Assessing Political Legitimacy and Operational Achievements', in Statebuilding in Afghanistan:

Multinational Contributions to Reconstruction. Ed. by Nik Hynek and Péter Marton. Routledge.

Hochwart, Michael A. 2009. 'The Provincial Reconstruction Teams in Afghanistan: A Model for Future Nation Building Operations', SAMS Monograph. Download PDF.

Hollanda, Kenneth. 2010. 'The Canadian Provincial Reconstruction Team: The Arm of Development in Kandahar Province', American Review of Canadian Studies, Volume 40, Issue 2.

Holt, Ronald L. 2009. 'Afghan Village Militia: A People-Centric Strategy to Win', Small Wars Journal, September 2009. Download PDF. 
Hope, Ian. 2008. 'Unity of Command in Afghanistan: A Forsaken Principle of War', Us Army War College. Download PDF.

Hughes, Geraint. 2008. 'The Soviet-Afghan War, 1978-1989: An Overview', Defence Studies, Vol. 8, No. 3.

Humayoon, Haseeb. 2007. 'The Iraqization of Insurgency in Afghanistan', Center for Conflict and Peace Studies, Kabul.

Hussain, Raja G. 2008. Badal, A Culture of Revenge: The Impact of Collateral Damage on Taliban Insurgency. Naval Postgraduate School Master's Thesis. Download PDF.

Jaeger, David A. and Zahra Siddique. 2011. 'Are Drone Strikes Effective in Afghanistan and Pakistan? On the Dynamics of Violence between the United States and the Taliban', IZA Discussion Paper No. 6262. Download PDF.

Jansen, C.R. 2010. 'The Kandahar Light Logistics Platoon', Canadian Army Journal, Vol. 12, No. 3. Download PDF.

Jebnoun, N. 2008. 'The Denial of Failure in Afghanistan', Small Wars Journal, PDF.

Jockel, Joseph and Sokolsky, Joel. 2008. 'Canada and the war in Afghanistan: NATO's odd man out steps forward', Journal of Transatlantic Studies, Vol. 6, No. 1, pp. 100-115.

Johnson, Thomas H. and M. Chris Mason. 2009 'Afghanistan and the Vietnam Template', Military Review, November-December 2009. Download PDF.

Johnson, Thomas H. 2007. 'The Taliban Insurgency and an Analysis of Shabnamah (Night Letters)', Small Wars and Insurgencies, Vol. 18, No. 3.

Johnson, Thomas H. and M. Chris Mason. 2007. 'Understanding the Taliban and Insurgency in Afghanistan,' Orbis, Winter 2007.

Jones, Seth G. 2008. 'Counterinsurgency in Afghanistan', RAND Report. PDF.

Jones, Seth G. 2007. 'The State of the Afghan Insurgency', Testimony for the Canadian Senate National Security and Defence Committee . RAND. December 2007. PDF.

Kan, Paul Rexton. 2011. 'Making a Sandwich in Afghanistan: How to Assess a Strategic Withdrawal from a Protracted Irregular War', Small Wars Journal, Vol. 7 No. 2. PDF.

Kemp, Robert E. 2011. 'Local Governance and COIN in Eastern Afghanistan 2004-2008', Military Review, January-February. Download PDF. 
Kemp, Robert E. 2011. 'Provincial Reconstruction Teams in Eastern Afghanistan: Utility as a Strategic Counterinsurgency Tool', Military Review (Sept-October). Download PDF.

Kemp, Robert. 2010. 'Counterinsurgency in Nangarhar Province, Eastern Afghanistan, 20042008', Military Review, November-December. Download PDF.

Kerry, John. 2009. 'Tora Bora Revisited: How we failed to get Bin Laden and why it matters today', A Report to the Committee on Foreign Relations, US Senate. PDF.

Khalil, Lydia. 2009. 'Iraq the Model? How Applying Lessons from our Successes and Failures in Iraq Can Shape a Winning Strategy in Afghanistan', Small Wars Journal, October 2009.

Download PDF.

Khan, Mehar Omar. 2009. 'Afghanistan: Seven Fundamental Questions', Small Wars Journal, November 2009. Download PDF.

Khan, M.O. 2009. 'Don't Try to Arrest the Sea: An Alternative Approach for Afghanistan', Small Wars Journal, October 2009. Download PDF.

Kilcullen, David. 2009. 'Taliban and Counter-Insurgency in Kunar', in Antonio Giustozzi (ed.) Decoding the New Taliban: Insights from the Afghan Field. Hurst/Columbia.

King, Anthony. 2011. 'Operation Herrick: The British Campaign in Helmand', in Statebuilding in Afghanistan: Multinational Contributions to Reconstruction. Edited by Nik Hynek and Péter Marton. Routledge.

Kinnunen, Eero and Lester W. Grau. 2011. 'Two Tours in Afghanistan: Twenty Years and Two Armies Apart', Military Review, May-June. Download PDF.

Kiss, Zoltan Laszlo. 2009. 'Hungarian experiences from peacekeeping in Afghanistan', Contributions to Conflict Management, Peace Economics and Development, Vol. 12(1).

Kolenda, Christopher. 2010. 'Winning Afghanistan at the Community Level', Joint Forces Quarterly, Issue 56. Download PDF.

Kotkin, Jeremy. 'Is the War in Afghanistan in the Interests of the United States and its Allies?', Small Wars Journal, August 2009. Download PDF.

Kraft, James E. 2008. Afghanistan: A War That Can Only Be Won via the Concentration of United States Elements of National Power. National Defense University, Master's thesis. PDF.

Kuchins, Andrew et al. 2009. 'The Northern Distribution Network and the Modern Silk Road', CSIS. Download PDF. 
Kuehne, Andreas. 2008. Scrutinizing and Assessing the Performance of the German and U.S.-led Provincial Reconstruction Teams in Afghanistan. Naval Postgraduate School Thesis. PDF.

Kugler, Richard. 2007. 'Operation Anaconda in Afghanistan: A Case Study of Adaptation in Battle', Case Studies in Defense Transformation, Number 5. PDF.

Langford, Ian. 2010. 'Australian Special Forces in Afghanistan: Supporting Australia in the 'Long War", Australian Army Journal, Vol. VII, Number 1. Download PDF.

Larsdotter, Kersti. 2008. 'Exploring the utility of armed force in peace operations: German and British approaches in northern Afghanistan', Small Wars \& Insurgencies, Vol. 19, No.3.

Ledford, Edward C. 2009. 'Inception and Early Evolution of a Partnership Doctrine: Building Afghan Army Capacity While Fighting a Counterinsurgency', Small Wars Journal, August. PDF.

Ledwidge, Frank. 2009. 'Justice and Counter-Insurgency in Afghanistan: A Missing Link', The RUSI Journal, Vol. 154, No. 1.

LeGree, Larry. 2010. 'Thoughts on the Battle for the Mind: IO and COIN in the Pashtun Belt', Military Review, September-October 2010. Download PDF.

Leigh, Ryan M. 2010. 'Thinking the unthinkable: civil war in Afghanistan', SAMS. PDF.

Liebl, Vern. 2007. 'Pushtuns, Tribalism, Leadership, Islam and Taliban: A Short View', Small Wars \& Insurgencies, 18(3), pp. $492-510$.

Litchfield, John D. 2010. 'Unconventional Counterinsurgency: Leveraging Traditional Social Networks and Irregular Forces in Remote and Ungoverned Areas', SAMS. Download PDF.

Lombardi, Ben. 2009. 'Talking to the Enemy: Some thoughts on what that means', Defence R\&D Canada. Download PDF.

Luehrs, Christoff. 2009. 'Provincial Reconstruction Teams: A Literature Review', Prism, Vol. 1, No. 1. Download PDF.

Maher, William. 2010. 'From the Andes to the Hindu Kush: Colombian Airpower Lessons for Afghanistan', SAMS Monograph. Link to PDF.

Malevich, John J. and Daryl C. Youngman. 2011. 'The Afghan Balance of Power and the Culture of Jihad', Military Review, May-June. Download PDF.

Maley, William. 2011. 'PRT Activity in Afghanistan: The Australian Experience', in Statebuilding in Afghanistan: Multinational Contributions to Reconstruction. Edited by Nik Hynek and Péter Marton. Routledge. 
Malkasian, Carter and Gerald Meyerle. 2009. 'Provincial Reconstruction Teams: How do we know they work?', Strategic Studies Institute. Download PDF.

Maloney, Sean M. 2008. 'A violent impediment: the evolution of insurgent operations in Kandahar province 2003-07', Small Wars \& Insurgencies, Vol. 19, No. 2, pp. 201-220.

Maloney, Sean M. 2007. 'Conceptualizing the War in Afghanistan: Perceptions from the Front, 2001-2006', Small Wars \& Insurgencies, Vol. 18, No. 1.

Mann. S. 2008. 'Taking Interagency Stability Operations to a New Level: The Integration of Special Operation Forces and USAID in Afghanistan', Small Wars Journal. PDF.

Marston, Daniel. 2008. 'Lessons in 21st-Century Counterinsurgency: Afghanistan 2001-2007', in Counterinsurgency in Modern Warfare, edited by Daniel Marston and Carter Malkasian. Osprey Publishing.

Marston, Daniel. 2008. 'British Operations in Helmand Afghanistan', Small Wars Journal. PDF.

Martin, Grant. 2011. 'A Tale of Two Design Efforts (and why they both failed in Afghanistan)', Small Wars Journal (July). Download PDF.

Martin, Grant M. 2009. 'Special Operations and Conventional Forces: How to Improve Unity of Effort Using Afghanistan as a Case Study', SAMS Monograph. Link to PDF.

Marton, Péter and Péter Wagner. 2008. 'The Netherlands and Hungary's contribution to operations in Afghanistan: Contributing to state-building or to crisis management?', HÍRLEVÉL. Hungarian Institute of International Affairs. Download PDF.

McChrystal, Stanley A. 2009. 'Afghanistan: NATO International Security Assistance Force Commander's Initial Assessment', NATO/ISAF. Download PDF.

McFeely, Eugene L. 2009. 'Balancing Kinetic Effects of Airpower with Counterinsurgency Objectives in Afghanistan', United States Army War College Strategic Research Project. PDF.

McKenna, Suzanne, et al. 2008. 'Agency Stovepipes vs Strategic Agility: Lessons We Need to Learn from Provincial Reconstruction Teams in Iraq and Afghanistan', U.S. House of Representatives, Committee on Armed Services. April 2008 Report. PDF.

Mcnab, R. and E. Mason. 2007. 'Reconstruction, the Long Tail and Decentralisation: An Application to Iraq and Afghanistan', Small Wars \& Insurgencies, Vol. 18, No. 3.

McNerney, Michael M. 2005. 'Stabilization and reconstruction in Afghanistan: are PRTs a model or a muddle', Parameters, Vol. 35, No. 4. Download PDF. 
Merz, Sebastian. 2007. 'Still on the way to Afghanistan? Germany and its forces in the Hindu Kush', SIPRI Project Paper. Download PDF.

Meyerle, Jerry, et al. 2010. 'Counterinsurgency on the Ground in Afghanistan: How different units adapted to local conditions' Center for Naval Analyses. PDF.

Millen, Raymond. 2008. 'Aligning a Counterinsurgency Strategy for Afghanistan', Small Wars Journal. Download PDF.

Mills, Greg. 2007. 'Ten Counterinsurgency Commandments from Afghanistan', April 2007. US Army War College. Download PDF.

Minkov, Anton. 2010. 'Counterinsurgency and Ethnic/Sectarian Rivalry in Comparative Perspective: Soviet Afghanistan and Contemporary Iraq', Tribal Engagement Workshop. PDF.

Minkov, Anton and Smolynec, Gregory. 2010. '4-D Soviet Style: Defence, Development, Diplomacy and Disengagement in Afghanistan During the Soviet Period Part I: State Building', The Journal of Slavic Military Studies, Vol. 23, No. 2.

Minkov, Anton and Smolynec, Gregory. 2010. '4-D Soviet Style: Defense, Development, Diplomacy, and Disengagement in Afghanistan During the Soviet Period. Part III: Economic Development', The Journal of Slavic Military Studies, Vol. 23, No. 4.

Minkov, Anton and Gregory Smolynec. 2007. '3-D Soviet Style: A Presentation on Lessons Learned from the Soviet Experience in Afghanistan', DRDC Centre for Operational Research \& Analysis, October 2007. Download PDF.

Moore, M. and J. Fussell. 2009. 'Kunar and Nuristan: Rethinking US Counterinsurgency Operations', Institute for the Study of War. Afghanistan Report \#1. Download PDF.

Nathan, Joanna. 2009. 'A Review of Reconciliation Efforts in Afghanistan', CTC Sentinel, Vol. 2, No. 8. Download PDF.

National Defence Canada. 2008. 'Counter-Insurgency Operations.' Download PDF.

NATO/ISAF. 2009. 'ISAF Commander's Counterinsurgency Guidance.' Download PDF.

NATO. 2008. 'NATO in Afghanistan: Master Narrative as at 6 October 2008', NATO Media Operations Centre. Download PDF.

Noetzel, Timo and Schreer, Benjamin. 2008. 'Counter-what? Germany and Counter-Insurgency in Afghanistan', The RUSI Journal, Vol. 153, No. 1, pp. 42-46. 
Noetzel, T. and B. Schreer. 2008 'The German Army and Counterinsurgency in Afghanistan', SWP Comments No. 1. Download PDF.

Nuzum, Henry. 2010. 'Shades of CORDS in the Kush: The False Hope of "Unity of Effort" in American Counterinsurgency', Strategic Studies Institute. Download PDF.

Oliker, Olga. 2004. Aid During Conflicts: Interaction Between Military and Civilian Assistance Providers in Afghanistan. RAND. Download PDF.

Olson, L. 2007. 'Civil-Military Coordination: Challenges and Opportunities in Afghanistan and Beyond', Journal of Military and Strategic Studies, Vol. 10, Issue 1.

O'Quinn, Charles R.V. 2006. Invisible scalpel: low-visibility operations in the War on Terror. Thesis (MMAS)-U.S. Army CGSC. Download PDF.

OSI/TLO. 2010. 'Strangers at the Door: Night Raids by International Forces Lose Hearts and Minds of Afghans', Open Society Institute // The Liaison Office. PDF.

PA Consulting. 2009. 'Dynamic Planning for COIN in Afghanistan.' Download PDF.

Park, David H. 2010. 'Identifying the Center of Gravity of Afghan Mentoring', Military Review, November-December. Download PDF.

Parker, Michelle. 2006. 'Programming Development Funds to Support a Counterinsurgency: A Case Study of Nangarhar, Afghanistan in 2006', Case Studies in National Security Transformation Number 10. Download PDF.

Pascall, Patrick. 2009. 'The Fire Model of Counterinsurgency: Focusing Efforts to Make an Insurgency Unsustainable', SAMS Monograph. Link to PDF.

Patterson, Rebecca and Jonathan Robinson. 2011. 'The Commander as Investor: Changing CERP Practices', PRISM 2, No. 2. Download PDF.

Pavilonis, Brigid Myers. 2010. 'Fighting the Irregular War in Afghanistan: Success in Combat Struggles in Stabilization', in The Routledge Handbook of War and Society: Iraq and Afghanistan. London: Routledge.

Peters, Gretchen. 2009. 'Incorporating Law Enforcement Interrogation Techniques on the Battlefield', CTC Sentinel, Vol. 2, Issue 7. Download PDF.

Petit, Brian. 2011. 'The Fight for the Village: Southern Afghanistan, 2010', Military Review, MayJune. Download PDF. 
Pike, Tom and Eddie Brown. 2011. 'Populations as Complex Adaptive Systems: A Case Study of Corruption in Afghanistan', Small Wars Journal (August). Download PDF.

Poitras, Maurice V. 2009. 'Adoptable Afghan Customs or Practices in a Military Operations Environment', SAMS Monograph. Download PDF.

Pritchard, J. and M. Smith. 2010. 'Thompson in Helmand: Comparing Theory to Practice in British Counter-insurgency Operations in Afghanistan', Civil Wars, Vol. 12, No. 1.

Proud, Matt. 2011. 'The Coin Environment: The Integration and Execution of Lethal and NonLethal Effects at the Tactical Level', Australian Army Journal, Volume VIII, Number 1. PDF.

Prugh, Dave. 2010. 'Lessons Learned from Six and a Half Years in Afghanistan', Small Wars Journal, Vol. 6, No. 3. Download PDF.

Račius, Egdunas. 2011. 'Trials and Tribulations of the Lithuanian Participation in the NATO ISAF Mission', in Statebuilding in Afghanistan: Multinational Contributions to Reconstruction. Edited by Nik Hynek and Péter Marton. Routledge.

Raghuvanshi, Vivek. 2010. 'Competitive Intelligence Insight - Dealing with Insurgency in Iraq, Afghanistan and India', eZine. Link to PDF.

Rapone, David J. 2010. 'Engaging the Insurgent in Negotiation: Lessons from Northern Ireland Applied to Afghanistan', SAMS Monograph. Link to PDF.

Rhyne, Richard G. Jr. 2004. Special Forces command and control in Afghanistan. Thesis (MMAS)-U.S. Army Command and General Staff College (CGSC). Download PDF.

Riedel, Bruce. 2009. 'Comparing the U.S. and Soviet Experiences in Afghanistan', CTC Sentinel, Vol. 2, Issue 5. Download PDF.

Rietjens, S. et al. 2009. 'Inter-organisational communication in civil-military cooperation during complex emergencies: a case study in Afghanistan', Disasters, Vol. 33, No. 3.

Rietjens, S. 2008. 'Managing Civil-Military Cooperation: Experiences from the Dutch Provincial Reconstruction Team in Afghanistan', Armed Forces and Society, 34(2).

Rietjens, Sebastiaan J. H. 2006. Civil-military cooperation in response to a complex emergency: just another drill? PhD thesis. University of Twente, Netherlands. PDF.

Ringsmose, Jens and Peter Dahl Thruelsen. 2010. 'NATO's counterinsurgency campaign in Afghanistan: are classical doctrines suitable for alliances?', UNISCI Discussion Papers. PDF. 
Rodano, Matthew Q. 2011. 'The Road to Reconciliation: Disarmament, Demobilization, and Reintegration', Military Review (September-October). Download PDF.

Rogers, Bruce, Jim Hope and Robert Kemp. 2008. 'PRTs in Afghanistan: A report from the inside', Foreign Service Journal, Vol. 85, No. 7. Download PDF.

Ruiz, Moses T. 2009. 'Sharpening the Spear: The United States' Provincial Reconstruction Teams in Afghanistan', MPA thesis, Texas State University. PDF.

Runge, Peter. 2009. 'The Provincial Reconstruction Teams in Afghanistan: Role model for civilmilitary relations?', BICC Occasional Paper IV. Download PDF.

Saideman, Stephen M. and David P. Auerswald. 2009. 'NATO at War: Understanding the Challenges of Caveats in Afghanistan', APSA 2009 Toronto. Link to PDF.

Salonius-Pasternak, Charly. 2011 'Finland's ISAF experience: Rewarding, Challenging and on the Edges of the Politically Feasible', in Statebuilding in Afghanistan: Multinational Contributions to Reconstruction. Edited by Nik Hynek and Péter Marton. Routledge.

Schreer, Benjamin. 2010. 'Political Constraints: Germany and Counterinsurgency', Security Challenges, Vol. 6, No. 1.

St-Louis, Michel-Henri. 2009. 'The Strategic Advisory Team in Afghanistan: Part of the Canadian Comprehensive Approach to Stability Operations', Canadian Military Journal, Vol. 9, No. 3. Download PDF.

Salmon, Paul J. 2008. 'The Role of the Provincial Reconstruction Teams in Stability Operations: Reality and Potential', SAMS Monograph. Download PDF.

Sanders, Gregory. 2009. 'Contracting for Operations in Iraq and Afghanistan', DIIG Current Issues No. 17. CSIS. Download PDF.

Schmidt, Soren. 2009. 'Afghanistan: Organizing Danish Civil Military Relations', DIIS Report 15. Download PDF.

Scott, Trent and John Agoglia. 2008. 'Getting the Basics Right: A Discussion on Tactical Actions for Strategic Impact in Afghanistan, Small Wars Journal. Download PDF.

Sedra, M. 2005. 'Civil-Military Relations in Afghanistan: The Provincial Reconstruction Team Debate”, Canadian Institute of Strategic Studies Strategic Datalink, No. 126.

Seitz, Paul T. 2007. 'The Future of the Afghan Insurgency', USAWC Strategy Research Project. Download PDF. 
Sellers, Cameron S. 2007. 'Provincial Reconstruction Teams: Improving Effectiveness', Naval Postgraduate School Master's Thesis. Download PDF.

Shaw, Geoff and David Spencer. 2003. 'Fighting in Afghanistan: Lessons from the Soviet Intervention, 1979-89', Defense \& Security Analysis, Vol. 19, No. 2.

SIGAR. 2010. 'Actions Needed to Improve the Reliability of Afghan Security Force Assessments', Special Inspector General for Afghanistan Reconstruction. PDF.

Sims, Christopher. 2012. 'Fighting the Insurgents' War in Afghanistan', Small Wars Journal (January). Download PDF.

Slaikeu, Karl A. 2009. 'Winning the War in Afghanistan: An Oil Spot Plus Strategy for Coalition Forces', Small Wars Journal, April 2009. Download PDF.

Slaughter, Sean R. 2010. 'Expanding the Qawm: Culturally Savvy Counterinsurgency and NationBuilding in Afghanistan', SAMS Monograph. Link to PDF.

Snyder, Vic. 2008. 'Strategic Agility for 21st Century Challenges: Interagency Lessons from Provincial Reconstruction Teams', Address by Rep. Vic Snyder. Audio online.

Spencer, David K. 2009. 'Afghanistan's Nangarhar Inc: A Model for Interagency Success', Military Review, July-August 2009. Download PDF.

Spiszer, John M. 2011. 'Counterinsurgency in Afghanistan-Lessons Learned by a Brigade Combat Team', Military Review, January-February. Download PDF.

Stapleton, B. 2007. 'A Means to what end? Why PRTs are peripheral to the bigger political picture in Afghanistan', Journal of Military and Strategic Studies, Vol. 10(1).

Sterzer, Marcus et al. 2008. 'Note to File-The Challenge of Centralized Control Faced by the Intelligence Function in Afghanistan', Canadian Army Journal, 11(2). PDF.

Strand, Arne. 2010. 'Drawing the lines: the Norwegian debate on civilian-military relations in Afghanistan', NOREF. Download PDF.

Strick van Linschoten, Alex and Felix Kuehn. 2011. 'A Knock on the Door: 22 Months of ISAF Press Releases', Afghanistan Analysts Network. Download PDF.

Strickland, R. 2008. 'The Taliban in Afghanistan', Canadian Army Journal, 11(1). PDF.

Sturek, Frank. 2007. 'Counter-insurgency in Afghanistan - A Way It Was Done in OEF VII \& ISAF IV (2006) ', $2^{\text {nd }}$ Annual Baltic Conference on Defence. Download PDF. 
Thomas, R. 2009. 'Origins of the Strategic Advisory Team: Afghanistan', On Track, Vol. 14(1).

Thompson, Carl. 2009. 'Winning in Afghanistan', US Army. Download PDF.

Thruelsen, Peter Dahl. 2010. Fighting an insurgency without unity: NATO in Afghanistan, 2006 to 2010. PhD thesis, University of Copenhagen. PDF.

Thruelsen, Peter Dahl. 2008. 'Counterinsurgency and a Comprehensive Approach: Helmand Province, Afghanistan', Small Wars Journal. Download PDF.

Thruelsen, Peter Dahl. 2007. 'NATO in Afghanistan: What Lessons are we learning and are we willing to adjust?', Danish Institute for Int. Studies Report No. 14. Download PDF.

Turner, L.S. et al. 2010. 'Optimizing Deadly Persistence in Kandahar: Armed UAV Integration in The Joint Tactical Fight', Canadian Army Journal, Vol. 13, No. 1. Download PDF.

Vamvakas, Petros. 2011. 'Turkey's ISAF Mission: A Maverick with Strategic Depth', in Statebuilding in Afghanistan: Multinational Contributions to Reconstruction. Edited by Nik Hynek and Péter Marton. Routledge.

Valadez, Ignacio R. 2009. 'Afghanistan, A Path to Success', Naval War College report. PDF.

Williams, Brian Glyn. 2008. 'Talibanistan: History of a Transnational Terrorist Sanctuary', Civil Wars, Vol. 10, No. 1.

Williams, Brian Glyn. 2008. 'Afghanistan's Heart of Darkness: Fighting the Taliban in Kunar Province', CTC Sentinel, Vol. 1, Issue 11. Download PDF.

Williams, Jason T. 2009. 'Understanding an Insurgency: Achieving the United States' Strategic Objectives in Afghanistan', SAMS Monograph. Download PDF.

Willis, Michael S. 2010. 'Contrasts between American and Afghan warriors, a comparison between two martial cultures', Master's thesis, U.S. Army Command and General Staff College. Download PDF.

Wilner, Alex S. 2010. 'Targeted Killings in Afghanistan: Measuring Coercion and Deterrence in Counterterrorism and Counterinsurgency', Studies in Conflict \& Terrorism, Vol. 33, No. 4.

Zabih Ullah. 2010. 'A view from Kandahar: How Afghans View Coalition Military Operations in Kandahar', Lowy Institute. Link to PDF.

Zweibelson, Ben. 2010. 'The US in Afghanistan: Follow Sun Tzu rather than Clausewitz to Victory', Small Wars Journal, Vol. 6, No. 11. Download PDF. 


\section{Security Sector: DDR, Militias, ANA, ANP, and Security Contractors}

Arfsten, Darryl et al. 2012. 'Drug Use Among the Afghanistan National Police: A National Assessment', Military Medicine, Volume 177, Number 1.

Ayub, Fatima, et al. 2009. 'Security Sector Reform in Afghanistan', International Center for Transitional Justice. Download PDF.

Azami, Sharif. 2009. 'The Need for Security Sector Reform in Afghanistan to Curb Corruption', Peace and Conflict Monitor, November. Read online.

Bhatia, Michael and R. Muggah. 2008. 'The Politics of Demobilization in Afghanistan', in Security and Post-Conflict Reconstruction. Ed. by Robert Muggah. Routledge.

Bhatia, Michael. 2007. 'The Future of the Mujahideen: Legitimacy, Legacy, and Demobilization in Post-Bonn Afghanistan', International Peacekeeping, Vol. 14, No. 1.

Bhatia, Michael, Kevin Lanigan and Philip Wilkinson. 2004. 'Minimal Investments, Minimal Results: The Failure of Security Policy in Afghanistan', AREU. Download PDF.

Boera, Michael R. and Paul R. Birch. 2011. 'Rebuilding Afghanistan's National Security Forces: Fighting Asymmetry with Symmetry', Military Review, March-April. PDF.

Brooking, Steve and S. Schmeidl. 2008. 'When nobody guards the guards: The quest to regulate private security companies in Afghanistan', Sicherheit und Frieden/Security and Peace, Vol. 4.

Chan, Samuel. 2009. 'Sentinels of Afghan Democracy: The Afghan National Army', Military Review, January-February 2009. Download PDF.

Chan, Samuel. 2007. 'Sentinels of Afghan Democracy: The Afghan National Army', S. Rajaratnam School of International Studies Working Paper No. 128. Download PDF.

CIGI. 2009. 'Security Sector Reform Monitor \#2: Afghanistan', Center for International Governance Innovation. Download PDF.

CIGI. 2009. 'Security Sector Reform Monitor: Afghanistan [July 2009]', Center for International Governance Innovation. Download PDF. 
Clegg, Will. 2009. 'Irregular Forces in Counterinsurgency Warfare', Security Challenges, Volume 5, Number 3. Download PDF.

Cordesman, Anthony H. 2010. 'Afghan National Security Forces: What It Will Take to Implement the ISAF Strategy', CSIS. Download PDF.

Cordesman, Anthony H. et al. 2009. 'Winning in Afghanistan: Creating Effective Afghan Security Forces', CSIS. Download PDF.

Cordesman, Anthony. 2009. 'Afghan National Security Forces: Shaping the Path to Victory', CSIS. Download PDF.

Cordesman, Anthony. 2009. 'Afghan National Security Forces: Shaping Host Country Forces as Part of Armed Nation Building', CSIS. Download PDF.

Cordesman, Anthony H. 2009. 'Shaping Afghan National Security Forces: What It Will Take To Implement President Obama's New Strategy', CSIS. Download PDF.

Cramer, Sarah. 2011. 'Women's Perceptions of the Afghan National Police: Gender dynamics of Kabul women and police', Heinrich Böll Stiftung. Download PDF.

Cronin, Stephanie. 2011. 'Building and Rebuilding Afghanistan's Army: An Historical Perspective', Journal of Military History, Vol. 75, No. 1.

CRS. 2009. 'Department of Defense Contractors in Iraq and Afghanistan: Background and Analysis [December 2009]', Congressional Research Service. Download PDF.

Deflem, Mathieu. 2010. 'Policing Afghanistan: Civilian Police Reform and the Resurgence of the Taliban', in The Routledge Handbook of War and Society: Iraq and Afghanistan. Routledge.

Dennys, Christian and Tom Hamilton-Baillie. 2012. 'Strategic Support to Security Sector Reform in Afghanistan, 2001-2010', SSR Issue Papers, No. 6. Download PDF.

Eliason, Eric A. 2008. 'Training Afghan and Iraqi Military Chaplaincies: A Battle-proven Model from an Experiment in Afghan Indigenous Chaplain Training.' Download PDF.

Flight, N. 2010. 'Optimizing Canada's Commitment to Police Reform in Afghanistan', Canadian Army Journal, Vol. 13, No. 1. Download PDF.

Friesendorf, Cornelius. 2011. 'Paramilitarization and Security Sector Reform: The Afghan National Police', International Peacekeeping, Vol.18, No.1.

Giustozzi , Antonio and Mohammed Isaqzadeh. 2012. Policing Afghanistan: The Politics of the Lame Leviathan. Hurst \& Co. 
Giustozzi, Antonio and Mohammad Isaqzadeh. 2011. 'Afghanistan's Paramilitary Policing in Context. The Risks of Expediency', Afghanistan Analysts Network. PDF.

Giustozzi, Antonio. 2009. 'The Afghan National Army: Unwarranted Hope?', The RUSI Journal, Vol. 154, No. 6.

Giustozzi, Antonio. 2008. 'Afghanistan's National Army: The Ambiguous Prospects of Afghanization', Terrorism Monitor, Vol. 6, Issue 9. Read online.

Giustozzi, Antonio. 2008. 'Bureaucratic façade and political realities of disarmament and demobilisation in Afghanistan', Conflict, Security \& Development, Vol. 8, No. 2.

Giustozzi, Antonio. 2008. 'Shadow Ownership and SSR in Afghanistan', in Local Ownership and Security Sector Reform. Edited by Timothy Donais. LIT Verlag. PDF.

Giustozzi, Antonio. 2007. 'The privatizing of war and security in Afghanistan: future or dead end?', The Economics of Peace and Security Journal, Vol. 2, No. 1.

Giustozzi, Antonio. 2007. 'Auxiliary Force or National Army? Afghanistan's 'ANA' and the Counter-Insurgency Effort, 2002-2006', Small Wars and Insurgencies, Vol. 18, No. 1.

Giustozzi, Antonio. 2003. 'Military Reform in Afghanistan', pp. 23-32 in Brief 28, Confronting Afghanistan's Security Dilemma: Reforming the Security Sector, Mark Sedra (ed.). Bonn International Center for Conversion. Download PDF.

Giustozzi, Antonio. 2002. 'Afghanistan: The Problems of Creating a New Afghan army- and the critical dangers of failure!', International Industrial Information (April). PDF.

Government Accountability Office. 2011. 'Afghan Army Growing, but Additional Trainers Needed; Long-term Costs Not Determined.' US Government Accountability Office. PDF.

Government Accountability Office. 2008. 'Afghanistan Security: U.S. Efforts to Develop Capable Afghan Police Forces Face Challenges and Need a Coordinated, Detailed Plan to Help Ensure Accountability', U.S. Government Accountability Office. Download PDF.

Government Accountability Office. 2005. 'Afghanistan security: efforts to establish army and police have made progress, but future plans need to be better defined', United States Government Accountability Office (June 2005). Download PDF.

Hartzell, Caroline. 2011. 'Missed Opportunities: The Impact of DDR on SSR in Afghanistan', USIP. Download PDF. 
Helmer, Daniel. 2008. 'Twelve Urgent Steps for the Advisor Mission in Afghanistan', Military Review, July-August 2008. Download PDF.

Howk, Jason C. 2009. 'A Case Study in Security Sector Reform: Learning from Security Sector Reform/Building in Afghanistan (October 2002-September 2003)', Strategic Studies Institute. Download PDF.

International Crisis Group. 2008. 'Policing in Afghanistan: Still Searching for a Strategy', Asia Briefing No. 85. Access online.

Jalali, Ali A. 2009. 'The Future of Security Institutions', in The Future of Afghanistan, edited by J. Alexander Thier. United States Institute of Peace. Download PDF.

Jones, Seth and Arturo Munoz. 2010. 'Afghanistan's Local War: Building Local Defense Forces', RAND. Download PDF.

Klem, B. and P. Douma. 2008. 'The struggle after combat: the role of NGOs in DDR processes, synthesis study', CORDAID. Download PDF.

Kouvo, Sari et al. 2009. 'Security Sector Reform in Afghanistan', Initiative for Peacebuilding and International Centre for Transitional Justice. Download PDF.

Lefèvre, Mathieu. 2010. 'Local Defence in Afghanistan: A review of government-backed initiatives', Afghanistan Analysts Network. Download PDF.

Legon, Andrew. 2009. 'Ineffective, Unprofessional, and Corrupt: The Afghan National Police Challenge', Foreign Policy Research Institute. Read Online.

Lurås, Helge. 2010. 'Build-up of Afghan security forces ill advised', Norwegian Institute of International Affairs (NUPI). Download PDF.

Marten, Kimberly. 2009. 'The Danger of Tribal Militias in Afghanistan', Journal of International Affairs, Vol. 63, No. 1.

McBrewster, John et al (Eds.). 2009. Afghan National Army: Battle of Musa Qala, Operation Panther's Claw, Operation Strike of the Sword, Afghan National Army Air Corps. Alphascript Publishing.

Murray, Tonita. 2007. 'Police-Building in Afghanistan: A Case Study of Civil Security Reform', International Peacekeeping, 14(1), pp. 108-126.

O'Brien, Paul and Paul Barker. 2003. 'Old Questions Needing New Answers: A Fresh Look at Security Needs in Afghanistan', in Confronting Afghanistan's Security Dilemma: Reforming the Security Sector, Mark Sedra (ed.). BICC. Download PDF. 
Oxfam. 2011. 'No Time to Lose Promoting the Accountability of the Afghan National Security Forces.' Download PDF.

Perito, Robert M. 2009. 'Afghanistan's Police: The Weak Link in Security Sector Reform', USIP. Download PDF.

Pomper, Stephen D. 2005. 'Don't Follow the Bear: The Soviet Attempt to Build Afghanistan's Military', Military Review, (Sept.-Oct.). Download PDF.

Rossi, Simonetta and Antonio Giustozzi. 2006. 'Disarmament, demobilization, and reintegration of ex-combatants (DDR) in Afghanistan: constraints and limited capabilities', Crisis States Research Centre, Working paper no. 2, series 2. PDF.

Rubin, B. 2003. 'Identifying Options and Entry Points for Disarmament, Demobilization, and Reintegration in Afghanistan', in Confronting Afghanistan's Security Dilemma: Reforming the Security Sector. Mark Sedra (ed.). BICC. Download PDF.

Sato, Mami. 2011. 'Disarmament, demobilization, reintegration, and natural resources in Afghanistan', Environmental Law Institute. Download PDF.

Sedra, Mark. 2011. 'Afghanistan and the folly of apolitical demilitarisation', Conflict, Security \& Development, Volume 11, Issue 4.

Stapleton, Barbara. 2009. 'Disarming the Militias - DDR and DIAG and the Implications for Peace Building', Swedish Committee for Afghanistan Conference: Peace Building in Afghanistan. Download PDF.

Schetter, Conrad. 2002. 'Challenging the warlord culture: security sector reform in post-Taliban Afghanistan', BICC Paper \#25. Download PDF.

Schmeidl, Susanne and Karokhail, Masood. 2009. 'The Role of Non-State Actors in 'CommunityBased Policing' - An Exploration of the Arbakai (Tribal Police) in South-Eastern Afghanistan', Contemporary Security Policy, Vol. 30, No. 2.

Schmeidl, Susanne. 2009. 'The Good, the Bad and the Ugly - The Private Military and Security Sector in Afghanistan', in Alex Dowling and Eden Cole (eds.) Security Sector Governance in Afghanistan. DCAF.

Schmeidl, Susanne. 2008. 'Case Study Afghanistan', pp.9-38 in Ulrike Joras and Adrian Schuster (eds.) Private Security Companies and Local Populations: An Exploratory Study of Afghanistan and Angola. Working Paper 1/2008. Download PDF. 
Schmeidl, Susanne. 2007. 'Case Study Afghanistan - Who Guards the Guardians?', pp.14-45 in Private Security Companies and Local Populations. An exploratory study of Afghanistan and Angola. Swisspeace report. Download PDF.

Schwartz, Moshe. 2010. 'The Department of Defense's Use of Private Security Contractors in Iraq and Afghanistan: Background, Analysis, and Options for Congress', Congressional Research Service. Download PDF.

Sedra, Mark. 2010. 'Missed Opportunities: The European Union and Security Sector Reform in Afghanistan', in The Politics of Security Sector Reform: Challenges and Opportunities for the European Union's Global Role. Edited by Magnus Ekengren and Greg Simons. Ashgate.

Sedra, Mark. 2006. European Approaches to Security Sector Reform: Examining Trends through the Lens of Afghanistan', European Security, Vol. 15, No. 3.

Sedra, Mark. 2006. 'Security Sector Reform in Afghanistan: The Slide towards Expediency', International Peacekeeping, Volume 13, Number 1.

Sedra, Mark. (ed.) 2003. Confronting Afghanistan's Security Dilemma: Reforming the Security Sector, Bonn International Center for Conversion. Download PDF.

Sedra, Mark. 2003. 'Introduction', in Brief 28, Confronting Afghanistan's Security Dilemma: Reforming the Security Sector. Mark Sedra (ed.). BICC. Download PDF.

Sedra, Mark. 2003. 'Police Reform in Afghanistan: An Overview', pp. $32-39$ in Brief 28, Mark Sedra (ed.). Bonn International Center for Conversion, September 2003. PDF.

Sherman, Jake and Victoria DiDomenico 2009. 'The Public Cost of Private Security in Afghanistan', Center on International Cooperation. Download PDF.

SIGAR. 2010. 'Actions Needed to Improve the Reliability of Afghan Security Force Assessments', Special Inspector General for Afghanistan Reconstruction. PDF.

Simonelli, M. 2009. Riding a Donkey Backwards Through Afghanistan. Mill City Press.

Skinner, Marcus. 2008. 'Counterinsurgency and State Building: An Assessment of the Role of the Afghan National Police', Democracy and Security, Vol. 4, No. 3.

Stevens, Michael. 2011. 'Community Defence In Afghanistan: A Model For Future Stabilisation?', The RUSI Journal, Volume 156, Issue 3.

Tariq, Mohammad Osman. 2009. 'Community-based Security and Justice: Arbakai in Afghanistan', IDS Bulletin, Vol. 40, No. 2. 
UNDP. 2011. 'Afghanistan Police Perception Survey 2010', United Nations Development Programme // Afghan Center for Socio-Economic and Opinion Research. Download PDF.

US Senate. 2010. 'Inquiry into the role and oversight of private security contractors in Afghanistan', Armed Services Committee. Download PDF.

Various authors. 2008. 'Oversight of U.S. Efforts to Train and Equip Police and Enhance the Justice Sector in Afghanistan', Subcommittee on National Security and Foreign Affairs oversight hearing. Download PDF.

Waltemate, Sascha. 2011. 'Focused District Development - Turning Point for Police Building in Afghanistan?', DIAS-Analysen No. 47. Link to PDF.

Wilder, Andrew. 2007. 'Cops or Robbers? The Struggle to Reform the Afghan National Police', AREU. Download PDF.

Younossi, Obaid. 2009. The Long March: Building an Afghan National Army. RAND. PDF. 


\section{Human rights}

Afghanistan Independent Human Rights Commission. 2008. 'From Hope to Fear: An Afghan Perspective on Operations of Pro-Government Forces in Afghanistan', Afghanistan Independent Human Rights Commission. Download PDF.

Afghanistan Independent Human Rights Commission. 2007. 'Violations of International Humanitarian Law in Afghanistan: Practices of Concern and Example Cases 2007.' PDF.

Afghanistan Independent Human Rights Commission. 2006. 'Annual Report.' Read online.

Afghanistan Rights Monitor. 2011. 'ARM Annual Report: Civilian Casualties of War, JanuaryDecember 2010.' Download PDF.

Afghanistan Justice Project. 2005. 'Casting shadows: war crimes and crimes against humanity 1978-2001', The Afghanistan Justice Project, July 2005. Download PDF.

Amnesty International. 2009. 'Human Rights in Afghanistan', Amnesty International Report. Read online.

Amnesty International. 2008. 'Getting Away With Murder? The Impunity of International Forces in Afghanistan', Amnesty International. Download PDF.

Amnesty International. 2007. 'Afghanistan: All who are not friends, are enemies: Taleban abuses against civilians', Amnesty International. Download PDF.

ARM. 2009. 'The Winning Warlords: ARM's briefing paper on the role and influence of warlords and militia commanders in the August 2009 presidential election in Afghanistan', Afghanistan Rights Monitor. Download PDF.

Azarbaijani-Moghaddam, Sippi. 2007. 'On Living with Negative Peace and a Half-Built State: Gender and Human Rights', International Peacekeeping, 14(1), pp. 127-142.

Beg, Bator and Ali Payam. 2010. 'Charting a Course for a Sustainable Peace: Linking Transitional Justice and Reconciliation in Afghanistan', Afghanistan Watch. PDF.

Benini, Aldo A. and Lawrence H. Moulton. 2004. 'Civilian Victims in an Asymmetrical Conflict: Operation Enduring Freedom, Afghanistan', Journal of Peace Research, Vol. 41, No. 4.

Bohannon, John. 2011. 'Counting the dead in Afghanistan', Science, Vol. 331, No. 6022. 
Chesser, Susan G. 2012. 'Afghanistan Casualties: Military Forces and Civilians', CRS Report for Congress. Download PDF.

CIVIC. 2009. 'Losing the People: The Costs and Consequences of Civilian Suffering in Afghanistan', Campaign for Innocent Victims in Conflict. Download PDF.

Clark, Kate. 2011. 'The Layha: Calling the Taleban to Account', Afghanistan Analysts Network. Download PDF.

Everts, Dan. 2009. 'Afghanistan: The right mission on the wrong footing', Security and Human Rights, Vol. 20, No. 1.

Gossman, Patricia. 2005. 'Casting Shadows: War Crimes and Crimes against Humanity, 19782001', Afghan Justice Project. Download PDF.

Human Rights First. 2011. 'Detained and Denied in Afghanistan: How to Make U.S. Detention Comply with the Law.' Download PDF.

HRF. 2008. 'Private Security Contractors at War: Ending the Culture of Impunity', Human Rights First. Download PDF.

Human Rights Watch. 2008. "Troops in Contact": Airstrikes and Civilian Deaths in Afghanistan', Human Rights Watch. Download PDF.

Human Rights Watch. 2007. 'The Human Cost: The Consequences of Insurgent Attacks in Afghanistan', Human Rights Watch, Volume 19, No. 6(C), April 2007. Read online.

Human Rights Watch. 2006. 'By the Numbers: Findings of the Detainee Abuse and Accountability Project', (April 2006) Volume 18, No. 2(G). Download PDF.

Human Rights Watch. 2005. 'Blood-stained hands: past atrocities in Kabul and Afghanistan's legacy of impunity.' Download PDF.

Human Rights Watch. 2004. "'Enduring Freedom:" Abuses by U.S. Forces in Afghanistan ', (March 2004) Vol. 16, No. 3(C). Download PDF.

Human Rights Watch. 2003. " "Killing you is a very easy thing for us:" human rights abuses in southeast Afghanistan', Human Rights Watch Report, Vol. 15, No. 5(C). PDF.

Human Rights Watch. 2002. 'Fatally Flawed: Cluster Bombs and Their Use by the United States in Afghanistan', Vol. 14, No. 7 (G), December 2002. Download PDF. 
Human Rights Watch. 2002. 'Paying for the Taliban's Crimes: Abuses Against Ethnic Pashtuns in Northern Afghanistan', Human Rights Watch Report, Vol. 14(2C). PDF.

Human Rights Watch. 2002. " "We want to live as humans:" repression of women and girls in western Afghanistan', Human Rights Watch Report, Vol. 14, No. 11(C). PDF.

Human Rights Watch. 2002. " All our hopes are crushed:" violence and repression in western Afghanistan', Human Rights Watch Report, Viol. 14, No. 7(C). Download PDF.

International Organization for Migration. 2008. 'Trafficking in Persons in Afghanistan: Field Survey Report, June 2008.' Download PDF.

Keenan, Marla and Jonathan Tracy. 2010. 'United States Military Compensation to Civilians in Armed Conflict', CIVIC. Download PDF.

Kouvo, Sari and Dallas Mazoori. 2011. 'Reconciliation, Justice and Mobilization of War Victims in Afghanistan', The International Journal of Transitional Justice, Vol. 5, No. 3.

Nadery, Nader. 2009. 'A Human Rights Awakening?', in The Future of Afghanistan, edited by J. Alexander Thier. United States Institute of Peace. Download PDF.

Sajjad, Tazreena. 2009. 'These Spaces in between: The Afghanistan Independent Human Rights Commission and its Role in Transitional Justice', International Journal of Transitional Justice, Vol. 3, Issue 3.

Samar, Sima. 2009. 'The Need for Justice in Peace Building', Swedish Committee for Afghanistan Conference: Peace Building in Afghanistan. Download PDF.

Smith, Leanne M. 2008. 'Implementing International Human Rights Law in Post Conflict Settings - Backlash without Buy-In: Lessons from Afghanistan', Muslim World Journal of Human Rights, Vol. 5, Issue 1.

Thier, J Alexander and Azita Ranjbar. 2008. 'Killing Friends, Making Enemies: The Impact and Avoidance of Civilian Casualties in Afghanistan Source', United States Institute of Peace. Download PDF.

UNAMA. 2012. 'Afghanistan annual report 2011: protection of civilians in armed conflict', United Nations Assistance Mission in Afghanistan. Download PDF.

UNAMA/AIHRC. 2011. 'Afghanistan: annual report 2010 - protection of civilians in armed conflict', UNAMA Human Rights and the Afghanistan Independent Human Rights Commission. Download PDF. 
UNAMA. 2010. 'Afghanistan: annual report on protection of civilians in armed conflict, 2009', UNAMA, Human Rights. Download PDF.

UNHCHR. 2005. 'UN Mapping Report: Afghanistan', [suppressed and unpublished UN report on human rights abuses, 1978-2001]. Download PDF.

UNSC. 2008. 'Report of the Secretary-General on children and armed conflict in Afghanistan', United Nations Security Council. Download PDF.

US FOIA. 2009. 'The Dasht-e-Leili Massacre of Taliban prisoners of war, US FOIA, part I, 20022008', US Freedom of Information Act. Download PDF. Part 2: Download PDF

Waldman, Matt. 2009. 'Caught in the Conflict: Civilians and the international security strategy in Afghanistan', A briefing paper by eleven NGOs operating in Afghanistan for the NATO Heads of State and Government Summit, 3-4 April 2009. Download PDF.

Wali, Sima. 2004. 'Violence, terror, and accountability in Afghanistan', Peace Review, 16(1).

Watch List on Children and Armed Conflict. 2010. 'Setting the Right Priorities: Protecting Children Affected by Armed Conflict in Afghanistan.' Download PDF.

Winterbotham, Emily. 2012. 'Healing the Legacies of Conflict in Afghanistan Community Voices on Justice, Peace and Reconciliation', AREU. Download PDF.

Winterbotham, Emily. 2010. 'The State of Transitional Justice in Afghanistan: Actors, Approaches and Challenges', AREU. Download PDF. 


\section{Refugees and IDPs}

IDMC. 2010. 'Armed Conflict Forces Increasing Numbers of Afghans to Flee Their Homes', Internal Displacement Monitoring Forces. Download PDF.

IDMC. 2008. 'Afghanistan: Increasing hardship and limited support for growing displaced population', Internal Displacement Monitoring Centre. Download PDF.

Koser, Khalid and Susanne Schmeidl. 2009 'Displacement, Human Development, and Security in Afghanistan', pp.8-22 in Hady Amr (ed) Displacement in the Muslim World: A Focus on Afghanistan and Iraq. Saban Center. Download PDF.

Kronenfeld, Daniel A. 2008. 'Afghan Refugees in Pakistan: Not All Refugees, Not Always in Pakistan, Not Necessarily Afghan?', Journal of Refugee Studies, February.

Majidi, Nassim, 2008. 'Research Study on Afghan Deportees from Iran', Altai Consulting for ILOUNHCR. Download PDF.

Majidi, Nassim. 2009. 'Understanding the Return and Reintegration Process of Afghan Returnees from the UK', DFID. Download PDF.

Majidi, Nassim. 2009. 'Study on Cross Border Population Movements between Afghanistan and Pakistan', UNHCR. Download PDF.

Monsutti, Alessandro. 2010. 'Towards a Transnational Community: Migration and Remittances among the Hazaras', in Ethnicity, Authority, and Power in Central Asia: New Games Great and Small. Edited by Robert L. Canfield and Gabriele Rasuly-Paleczek. Routledge.

Monsutti, Alessandro. 2008. 'Afghan Migratory Strategies and the Three Solutions to the Refugee Problem', Refugee Survey Quarterly, Vol. 27, No. 1.

Monsutti, Alessandro. 2007. 'Migration as a Rite of Passage: Young Afghans Building Masculinity and Adulthood in Iran', Iranian Studies, Vol. 40, No. 2.

Monsutti, Alessandro. 2006. 'Afghan Transnational Networks: Looking Beyond Repatriation', AREU. Download PDF. 
Mundt, Alexander and Susanne Schmeidl, 2009. 'The Failure to Protect: Battle-Affected IDPs in Southern Afghanistan', The Brookings-Bern Project on Internal Displacement / The Liaison Office. Read online.

Mundt, Alexander, Susanne Schmeidl and Shafiqullah Ziai. 2009. 'Between a Rock and a Hard Place: The Return of Internally Displaced Persons to Northern Afghanistan', The Brookings-Bern Project on Internal Displacement/The Liaison Office. Read online.

Refugees International. 2010. 'Afghanistan: In a Time of Conflict', Refugees International, Field Report. Download PDF.

Refugees International. 2009. 'Afghanistan and Pakistan: Raise Voices for Civilian Protection', Refugees International. Download PDF.

Refugees International. 2008. 'Afghanistan: Invest in People.' Download PDF.

Schetter, Conrad. 2012. 'Translocal Lives. Patterns of Migration in Afghanistan', Crossroads Asia Working Paper Series, No. 2. Download PDF.

Schmeidl, Susanne. 2009. 'Repatriation to Afghanistan: durable solution or responsibility shifting?', Forced Migration Review, No. 33. 


\section{Opium: cultivation, drug use and trafficking}

Chouvy, Pierre-Arnaud. 2010. Opium: Uncovering the Politics of the Poppy. Harvard Uni Press.

Corti, Daniela and Ashok Swain. 2009. 'War on Drugs and War on Terror: Case of Afghanistan', Peace and Conflict Review, Volume 3, Issue 2. Download PDF.

Felbab-Brown, Vanda. 2009. Shooting Up: Counterinsurgency and the War on Drugs. Brookings Institution Press.

Felbab-Brown, Vanda. 2010. 'The Drug-Conflict Nexus in South Asia: Beyond Taliban Profits and Afghanistan', in The Afghanistan-Pakistan Theater: Militant Islam, Security \& Stability. Edited by Edited by Daveed Gartenstein-Ross \& Clifford D. May. Washington: FDD Press. PDF.

Felbab-Brown, Vanda. 2009. 'Peacekeepers Among Poppies: Afghanistan, Illicit Economies and Intervention', International Peacekeeping, Vol. 16, No. 1.

Felbab-Brown, Vanda. 2009. 'The Obama Administration's New Counternarcotics Strategy in Afghanistan: Its Promises and Potential Pitfalls', Brookings Policy Brief Series \#171. PDF.

Felbab-Brown, Vanda. 2006. 'Kicking the Opium Habit? Afghanistan's Drug Economy and Politics Since the 1980s', Journal of Conflict, Security, and Development, 6(2).

Felbab-Brown, Vanda. 2005. 'Afghanistan: When Counternarcotics Undermines Counterterrorism', The Washington Quarterly, 28(4). Download PDF.

Geller, Armando et al. 2011. 'How Corruption Blunts Counternarcotic Policies in Afghanistan: A Multiagent Investigation', in J. Salerno et al (eds.), Social Computing, Behavioral-Cultural Modeling and Prediction 2011 conference.

Geller, Armando et al. 2011. 'Persistence in the Political Economy of Conflict: The Case of the Afghan Drug Industry', AAAI Fall Symposium Series. pp. 86-92. Download PDF.

Goodhand, Jonathan. 2009. 'Bandits, Borderlands and Opium Wars: Afghan State-Building Viewed from the Margins', DIIS Working Paper 26. Download PDF.

Goodhand, Jonathan. 2008. 'Corrupting or Consolidating the Peace? The Drugs Economy and Post-conflict Peacebuilding in Afghanistan', International Peacekeeping, 15(3). 
Goodhand, Jonathan. 2005. 'Frontiers and Wars: the Opium Economy in Afghanistan', Journal of Agrarian Change, Vol. 5, No. 2.

Grare, Frédéric. 2008. 'Anatomy of a Fallacy: The Senlis Council and Narcotics in Afghanistan', CGI Working Paper No. 34.

Jelsma M . 2005. 'Learning Lessons from the Taliban Opium Ban', International Journal of Drug Policy, Volume 16, Number 2: pages 98-103.

Koehler, Jan and Zuercher, Christoph. 2007. 'Statebuilding, Conflict and Narcotics in Afghanistan: The View from Below', International Peacekeeping, 14:1, 62 - 74.

Maass, Citha D. 2011. 'Afghanistan's Drug Career: from War to Drug Economy', Afghanistan Analysts Network. Download PDF.

Mansfield, David and Adam Pain. 2008. 'Counter-Narcotics in Afghanistan: The Failure of Success?', AREU. Download PDF.

Mansfield, David. 2009. “"Poppy Free” Provinces: A Measure or a Target?',Afghanistan Research and Evaluation Unit. Download PDF.

Peters, Gretchen. 2009. 'How opium profits the Taliban', Peaceworks no. 62. USIP. PDF.

Peters, Gretchen S. 2009. 'The Taliban and the Opium Trade', in Antonio Giustozzi (ed.)

Decoding the New Taliban: Insights from the Afghan Field. Hurst/Columbia University.

Pothier, Fabrice. 2009. 'Opium in Afghanistan: a reality check', in Afghanistan: Now You See Me? IDEAS Strategic Update 001. March 2009. Download PDF.

Rubin, Barnett R. with Jake Sherman. 2008. 'Counter-narcotics to Stabilize Afghanistan: the false promise of crop eradication', CIC NYU. Download PDF. 


\section{State-Building: Governance, Development and Security}

\section{Books}

Beeres, Robert et al (editors). 2012. Mission Uruzgan: Collaborating in Multiple Coalitions for Afghanistan. Amsterdam University Press.

Bird, Tim and Alex Marshall. 2011. Afghanistan: How the West Lost Its Way. Yale Uni Press.

Caldwell, Dan. 2011. Vortex of Conflict: US Policy toward Afghanistan, Pakistan, and Iraq. Stanford Security Studies.

Carlton-Ford, Steven and Morten G. Ender (editors). 2010. The Routledge Handbook of War and Society: Iraq and Afghanistan. Routledge.

Danspeckgruber, Wolfgang (editor). 2011. Working Toward Peace and Prosperity in Afghanistan. Liechtenstein Colloquium Report, Volume 5. Lynne Rienner.

Danspeckgruber, Wolfgang and Robert P. Finn (editors). 2010. Building State and Security in Afghanistan. Lynne Rienner Publishers.

Dobbins, J. F. 2008. After the Taliban: Nation-Building in Afghanistan. Potomoc Books.

Ehrhart, Hans-Georg. 2012. Afghanistan in the Balance: Counterinsurgency, Comprehensive Approach, and Political Order. McGill-Queen's University Press.

Ehrhart, Hans-Georg and Charles C. Pentland. 2009. The Afghanistan Challenge: Hard Realities and Strategic Choices. School of Policy Studies Queen's University.

Girardet, Edward et al (eds.) 2004. Afghanistan: Essential Field Guide to Humanitarian and Conflict Zones. Media Action International.

Hanifi, Shah Mahmoud. 2008. Connecting Histories in Afghanistan: Market Relations and State Formation on a Colonial Frontier. Columbia University Press. Read online.

Hayes, Geoffrey and Mark Sedra (Editors). 2008. Afghanistan: Transition Under Threat. Wilfred Laurier University Press. 
Hussain, Imtiaz. 2010. Afghanistan, Iraq, and Post-conflict Governance: Damoclean Democracy? Brill Academic Publishers.

Hynek, Nik and Péter Marton (editors). 2011. Statebuilding in Afghanistan: Multinational Contributions to Reconstruction. Routledge.

Maley, William. 2007. Rescuing Afghanistan. London: Hurst \& Company.

Marsden, Peter. 2009. Afghanistan - Aid, Armies and Empires. I. B. Tauris.

Mason, Whit (editor). 2011. The Rule of Law in Afghanistan: Missing in Inaction. Cambridge University Press.

Nojumi, Neamatollah, Dyan Mazurana, Elizabeth Stites. 2008. After the Taliban: Life and Security in Rural Afghanistan. Rowman \& Littlefield Publishers.

Riecke, Henning (editor). 2012. Partners for Stability: Involving Neighbors in Afghanistan's Reconstruction - Transatlantic Approaches. Nomos Publishers.

Rotberg, Robert I. (editor). 2007. Building a New Afghanistan. Brookings Institute Press.

Saikal, Amin (editor). 2011. The Afghanistan Conflict and Australia's Role. Melbourne University Press.

Suhrke, Astri. 2012. When More Is Less: The International Project in Afghanistan. Columbia University Press.

Tondini. Matteo. 2010. Statebuilding and Justice Reform: Post-Conflict Reconstruction in Afghanistan. Routledge.

Zakheim, Dov S. 2011. A Vulcan's Tale: How the Bush Administration Mismanaged the Reconstruction of Afghanistan. Brookings Institution Press.

\section{Reports, articles, and book chapters}

AAN. 2009. 'Polling Day Fraud in the Afghan Elections', Afghanistan Analysts Network report. Download PDF.

Adlparvar, Naysan. 2010. 'Development in conflict: the politicisation of British aid to Afghanistan', Institute of Development Studies. 
Amiri, Ali and Abdul Jalil Benish. 2010. 'The First Experience: Voting Patterns and Political Alignments in Wolesi Jirga (2005-2010)', Afghanistan Watch. PDF.

Ahmed, Samina. 2001. 'State and Society in Afghanistan', IGD Occasional Paper, No. 29. PDF.

Allen, Nigel J.R. 2003. 'Rethinking governance in Afghanistan', Journal of International Affairs, Spring 2003, vol. 56, no. 1.

ANDS. 2008. 'Afghanistan National Development Strategy (2008-2013). Download PDF.

Atmar, Mohammed Haneef. 2001. 'Politicisation of Humanitarian Aid and Its Consequences for Afghans', Disasters, Vol. 25, No. 4.

Ayub, Fatima and Sari Kouvo. 2008. 'Righting the course? Humanitarian intervention, the war on terror and the future of Afghanistan', International Affairs, Vol 84, No. 4.

Barakat, Sultan. 2008. 'Understanding Afghanistan', DFID, The Recovery and Development Consortium. Download PDF.

Barfield, Thomas. 2010. 'Rebuilding Afghanistan', in Ethnicity, Authority, and Power in Central Asia: New Games Great and Small. Edited by Robert L. Canfield and Gabriele Rasuly-Paleczek. Routledge.

Barfield, T. 2008. 'The Roots of Failure in Afghanistan', Current History, December.

Barfield, Thomas, N. Nojumi, and J. A. Their. 2006. 'The Clash of Two Goods: State and NonState Dispute Resolution in Afghanistan', USIP. Download PDF.

Barikzai, Naweed. 2010. 'Afghan Parliamentary Process: democratically destabilizing', CAPS. Download PDF.

Barry, Michael. 2011. 'Kabul's Long Shadows: Historical Perspectives', Liechtenstein Institute. Download PDF.

Battiston, Giuliano. 2011. 'Afghan civil society: a look from within', Afgana.org. PDF.

Beath, Andrew, et al. 2011. 'Winning Hearts and Minds? Evidence from a Field Experiment in Afghanistan', MIT Political Science Department Research Paper. Link.

van Bijlert, Martine. 2010. 'Who Controls the Vote? Afghanistan's Evolving Elections', Afghanistan Analysts Network. Download PDF.

van Bijlert, Martine. 2010. 'Untangling Afghanistan's 2010 Vote: Analysing the electoral data', Afghanistan Analysts Briefing Paper, No. 3. Download PDF. 
van Bijlert, Martine. 2010. 'Imaginary Institutions: State-Building in Afghanistan', in Doing Good or Doing Better: Development Policies in a Globalising World. Monique Kremer et al. (eds). Amsterdam University Press.

van Bijlert, Martine. 2009 'How to Win an Afghan Election; Perceptions and Practices', Afghanistan Analysts Network. Download PDF.

van Bijlert, Martine. 2009. 'Between Discipline and Discretion: Policies Surrounding Senior Subnational Appointments', AREU. Download PDF.

Borchgrevink, Kaja. 2009. 'Negotiating Justice Sector Reform in Afghanistan', Crime, Law and Social Change, Vol. 51, No. 2.

Brick, Jennifer. 2008. 'The Political economy of Customary Village Organizations in Rural Afghanistan', Central Eurasian Studies Society, Washington, DC. Download PDF.

Buchholz, Benjamin. 2007. 'Thoughts on Afghanistan's Loya Jirga: A Myth?', Asien, Vol. 104 (July 2007), pp. 23-33. Download PDF.

Byrd, W. and S. Guimbert. 2009. 'Public Finance, Security, and Development: Framework and Application to Afghanistan', World Bank. Link to PDF.

Caldararo, Niccolo Leo. 2010. 'America in Afghanistan: Naivete, Greed and Good Intentions: An Anthropological View.' Link to PDF.

Chaudhuri, Rudra and Theo Farrell. 2011. 'Campaign disconnect: operational progress and strategic obstacles in Afghanistan, 2009-2011', International Affairs, 87(2).

Coburn, Noah. 2011. 'Political Economy of the Wolesi Jirga: Sources of Finance and their Impact on Representation in Afghanistan's Parliament', AREU. Download PDF.

Coburn, Noah and John Dempsey. 2010. 'Informal Dispute Resolution in Afghanistan' USIP Report. Download PDF.

Coburn, Noah. 2010. 'Parliamentarians and Local Politics in Afghanistan: Elections and Instability II', AREU. Download PDF.

Coburn, Noah. 2010. 'Connecting with Kabul: The Importance of the Wolesi Jirga Election and Local Political Networks in Afghanistan', AREU. Download PDF.

Coburn, Noah. 2010. 'Afghan Election, 2010: Alternative Narratives', AREU. PDF. 
Coburn, Noah. 2010. 'Connecting with Kabul: The Importance of the Wolesi Jirga Election and Local Political Networks in Afghanistan', AREU. Download PDF.

Coburn, Noah and Anna Larson. 2009. 'Voting Together: Why Afghanistan's 2009 Elections were (and were not) a Disaster', AREU. Download PDF.

Coburn, Noah and Anna Larson. 2009. 'Patronage, Posturing, Duty, Demographics Why Afghans Voted in 2009', AREU. Download PDF.

Coburn, Noah. 2009. 'Some Afghan Views on the Government, the International Community, and the 2009 Elections', AREU. Download PDF.

Coburn, Noah. 2008. 'Qaum: Conceptualizing Potters in the Afghan Political Arena', Boston University. Download PDF.

Connolly, David. 2010. 'Mid-term Evaluation of the National Solidarity Programme in Afghanistan', in Participatory Research Methodologies in Development and Post-

Disaster/Conflict Reconstruction. Edited by R. Bowd and A. Ozerdem. London: Ashgate.

Conway, Drew. 2010. 'Networks, Collective Action, and State Formation', Link.

Cookman, Colin and Caroline Wadhams. 2010. 'Governance in Afghanistan: Looking Ahead to What We Leave Behind', Center for American Progress. Download PDF.

Cordesman, Anthony H. 2011. 'The Failures That Shaped (and Almost Lost) the Afghan War', CSIS. Download PDF.

Cordesman, Anthony H. 2010. 'Afghanistan: A Progress Report', CSIS. PDFs.

Cordesman, Anthony H. 2010. 'How America Corrupted Afghanistan: Time to Look in the Mirror', CSIS. Download PDF.

Cordesman, Anthony H. and Jason Lemieux. 2010. 'The Afghan War: A Campaign Overview', CSIS. Download PDF.

Cordesman, Anthony and Nicholas Greenough. 2009. 'The Afghan-Pakistan War: Afghan Economics and Conditions of Life', CSIS. Download PDF.

Coyne, Christopher J. and Adam Pellillo. 2011. 'The Art of Seeing Like a State: State-Building in Afghanistan, the Congo, and Beyond.' Link to PDF.

Debiel, Tobias, Rainer Glassner, Conrad Schetter and Ulf Terlinden. 2009. 'Local State-Building in Afghanistan and Somaliland', Peace Review, Vol. 21, No. 1. 
Denissen, Marieke. 2009. 'Mutual Accountability in Afghanistan: Promoting Partnerships in Development Aid?', AREU. Download PDF.

Donini, Antonio. 2009. 'Afghanistan: humanitarianism under threat', Feinstein International Center. Download PDF.

Donini, Antonio. 2007. 'Local Perceptions of Assistance to Afghanistan', International Peacekeeping, 14(1), pp. $158-172$.

Durkin, J. Keller. 2009. 'Authority, Legitimacy, and the Qawm: Historical Perspectives on Emergent Governance in Afghanistan', SAMS Monograph. Download PDF.

Englehart, Neil A. 2010. 'A Tale of Two Afghanistans: Comparative Governance and Insurgency in the North and South', Asian Survey, Volume 50, No. 4.

Enterline, A. and J. Greig. 2009. 'Perfect Storms? Political Instability in Imposed Polities and the Futures of Iraq and Afghanistan', Journal of Conflict Resolution, Vol. 52, No. 6.

Esser, Daniel. 2009. 'Postwar Political Restructuring in Freetown and Kabul: Theoretical Limits and the Test Case for Multiscalar Governance', Critical Planning, Vol. 16.

Esser, Daniel. 2009. 'Who governs Kabul? Explaining urban politics in a post-war capital city', Crisis States Working Paper No. 43 (series 2). Download PDF.

Fänge, Anders. 2010. 'The State of the Afghan State', Afghanistan Analysts Network. PDF.

Fänge, Anders. 2009. 'The State, Conflict and International Assistance', Swedish Committee for Afghanistan Conference: Peace Building in Afghanistan. Download PDF.

Favre, Raphy. 2006. 'Local Shura, Security and development', AIZON Publication, Kabul. PDF.

Favre, Raphy. 2005. 'Interface between State and Society in Afghanistan', AIZON publication, Kabul. Download PDF.

Fayutkin, Dan. 2009. 'Stabilization \& Reconstruction of Nations after Military Conflict: Afghanistan and Chechnya Case Studies', Comparative Strategy, Vol. 28, Issue 4.

Fishstein, Paul and Andrew Wilder. 2012. 'Winning Hearts and Minds? Examining the Relationship between Aid and Security in Afghanistan', FIC. Download PDF.

Fishstein, Paul. 2010. 'Winning Hearts and Minds? Examining the Relationship between Aid and Security in Balkh Province', Feinstein International Center. Download PDF. 
Foust, Joshua. 2011. 'France in Kapisa: A Combined Approach to State-Building', in Statebuilding in Afghanistan: Multinational Contributions to Reconstruction. Edited by Nik Hynek and Péter Marton. Routledge.

Fraenkel, Eran, et al. 2010. 'Afghanistan Media Assessment: Opportunities and Challenges for Peacebuilding', USIP. Download PDF.

Frej, William M. and David Hatch. 2009. 'A New Approach to the Delivery of U.S. Assistance to Afghanistan', Prism, Vol. 1, No. 1. Download PDF.

Gang, Rebecca. 2011. 'Community-Based Dispute Resolution Processes in Kabul City', AREU. Download PDF.

Gang, Rebecca. 2010. 'Community-Based Dispute Resolution Processes in Balkh Province', AREU. Download PDF.

Gajewski, Gregory, et al. 2007. 'How War, a Tribal Social Structure, and Donor Efforts Shape Institutional Change in Afghanistan: A Case Study of the Roads Sector.' PDF.

Gall, Carlotta. 2009. 'Strategies for Enhancing Regional Security', Swedish Committee for Afghanistan Conference: Peace Building in Afghanistan. Download PDF.

Galtung, Fredrik and Martin Tisné, 2009. 'A New Approach to Postwar Reconstruction', Journal of Democracy, Volume 20 Number 4. Download PDF.

Gardizi, Manija, Karen Hussmann and Yama Torabi. 2010. 'Corrupting the State or State-Crafted Corruption? Exploring the Nexus between Corruption and Subnational Governance', AREU. Download PDF.

Geller, Armando. 2011. 'The Political Economy of Normlessness in Afghanistan', in Angela Schlenkhoff and Ceri Oeppen (eds.), Beyond the "Wild Tribes" - Understanding Modern Afghanistan and its Diaspora. New York: Columbia University Press.

Ghani, Ashraf. 2009. 'A Ten-Year Framework for Afghanistan: Executing the Obama Plan. . And Beyond', A Report by the Atlantic Council. Download PDF.

Giustozzi, Antonio and Claudio Franco. 2011. 'The Battle for Schools: The Taleban and State Education', Afghanistan Analysts Network. Download PDF.

Giustozzi, Antonio. 2010. 'Nation-Building Is Not for All; The Politics of Education', Afghanistan Analysts Network. Download PDF.

Giustozzi, Antonio and Orsini, Dominique. 2009. 'Centre-periphery relations in Afghanistan: Badakhshan between patrimonialism and institution-building', Central Asian Survey, 28(1). 
Giustozzi, Antonio. 2008. 'Afghanistan: transition without end. An analytical narrative of statemaking', Working Paper No: 40 (series 2). Download PDF.

Giustozzi, Antonio. 2003. 'Respectable warlords?: the politics of state-building in Afghanistan', Crisis States Research Centre, Working Paper No. 33. Download PDF.

Gompelman, Geert. 2011. 'Winning Hearts and Minds? Examining the Relationship between Aid and Security in Afghanistan's Faryab Province', Feinstein International Center. PDF.

Goodson, Larry and Thomas H. Johnson. 2011. 'Parallels with the Past: How the Soviets Lost in Afghanistan, How the Americans are Losing', FPRI. Download PDF.

Government Accountability Office. 2009. 'Afghanistan: Key Issues for Congressional Oversight', Government Accountability Office. April 2009. Download PDF.

Goodhand, Jonathan and Mark Sedra. 2009. 'Who owns the peace? Aid, reconstruction, and peacebuilding in Afghanistan', Disasters, March 2009.

Goodhand, Jonathan and Mark Sedra. 2007. 'Bribes or Bargains? Peace Conditionalities and 'Post-Conflict' Reconstruction in Afghanistan,' International Peacekeeping, 14(1).

Gordon, Stuart. 2011. 'Winning Hearts and Minds? Examining the Relationship between Aid and Security in Helmand Province', Feinstein International Center. Download PDF.

Haidari, M. Ashraf. 2009. 'Beyond the Elections: Key Lessons for International Peacekeeping in Afghanistan', Journal of International Peace Operations. PDF.

Hanifi, M. Jamil. 2004. 'Editing the Past: Colonial Production of Hegemony through the "Loya Jerga" in Afghanistan', Iranian Studies, 37(2).

Harpviken, Kristian Berg. 2011. 'A Peace Nation in the War on Terror: The Norwegian Engagement in Afghanistan', in Statebuilding in Afghanistan: Multinational Contributions to Reconstruction. Edited by Nik Hynek and Péter Marton. Routledge.

Harpviken, K. B. 2009. 'Peace Building and its Components - the State of the Art', Swedish Committee for Afghanistan Conference: Peace Building in Afghanistan. PDF.

Hasegawa, Y. 2008. 'The United Nations Assistance Mission in Afghanistan: Impartiality in New UN Peace Operations', Journal of Intervention and Statebuilding, Vol. 2, Issue 2.

Hendricks, Beau. 2010. 'Institutions and Organizations: Exploring the Interdependencies of Legitimacy Theory and Strategic Communication in Afghanistan', SAMS. PDF. 
Hess, Steve. 2010. 'Coming to terms with neopatrimonialism: Soviet and American nationbuilding projects in Afghanistan', Central Asian Survey, Vol. 29, No. 2.

Hudak, David and Francisco Baez. 2009. 'Cultural Geography Modelling and Analysis in Helmand Province', NATO. Word doc available online.

Humayoon, Haseeb. 2010. 'The Re-election of Hamid Karzai', ISW Afghanistan Report 4. PDF.

Hynek, Nik and Jan Eichler. 2011. 'Post-Decisional and Alliance-Dependent: The Czech Engagement in Logar', in Statebuilding in Afghanistan: Multinational Contributions to Reconstruction. Edited by Nik Hynek and Péter Marton. Routledge.

Karokhail, Masood and Susanne Schmeidl. 2006. 'Integration of Traditional Structures into the State-building Process: Lessons from the Tribal Liason Office in Paktia', Promoting Democracy under Conditions of State Fragility; Issue 1: Afghanistan. PDF.

Katzman, Kenneth. 2011. 'Afghanistan: Post-Taliban Governance, Security, and U.S. Policy', Congressional Research Service. Download PDF.

Khalilzad, Zalmay. 2010 'Lessons from Afghanistan and Iraq', Journal of Democracy, 21(3).

Kippen, Grant. 2009. 'The Long Democratic Transition', in The Future of Afghanistan, edited by J. Alexander Thier. United States Institute of Peace. Download PDF.

Kipping, Martin. 2010. 'Two Interventions: Comparing Soviet and US-led state-building in Afghanistan', Afghanistan Analysts Network. Download PDF.

Kouvo, Sari. 2009. 'State-building and rule of law: lessons from Afghanistan?', NDC Forum Paper No. 6, NATO Defense College. Download PDF.

Kulesa, Ł. and B. Górka-Winter. 2011. 'From Followers to Leaders as Coalition Servants: The Polish Engagement in Afghanistan', in Statebuilding in Afghanistan: Multinational Contributions to Reconstruction. Ed. by N. Hynek and P. Marton. Routledge.

Kuntzsch, Félix. 2008. 'Afghanistan's Rocky Road to Modernity: Non-State Actors and SocioPolitical Entities in the Process of State- and Nation-Building', Programme Paix et sécurité internationales (HEI). Download PDF.

Lafraie, Najibullah. 2009. 'NATO in Afghanistan: perilous mission, dire ramifications', International Politics, Vol. 46, No. 5.

Larsen, Iselin. 2010. 'UNAMA in Afghanistan: Challenges and Opportunities in Peacemaking, State-building and Coordination', Norwegian Institute of International Affairs. Download PDF. 
Larson, Anna. 2011. 'Deconstructing "Democracy" in Afghanistan', AREU. PDF.

Larson, Anna. 2010. 'Democratisation and Elections', AREU. Download PDF.

Larson, Anna. 2010. 'The Wolesi Jirga in Flux, 2010: Elections and Instability I', AREU. PDF.

Larson, Anna. 2010. 'Governance Structures in Nimroz Province', AREU. PDF.

Larson, Anna. 2009. 'Afghanistan's New Democratic Parties: A Means to Organise Democratisation?', AREU Briefing Paper. Download PDF.

Larson, Anna. 2009. 'Toward an Afghan Democracy? Exploring Perceptions of Democratisation in Afghanistan', AREU. Download PDF.

Larsson, Katarina. 2008. 'A Provincial Survey of Balkh, Jowzjan, Samangan and Saripul', Swedish Committee for Afghanistan. Download PDF.

Leonardo, Ernest. 2009. 'Assessment of Corruption in Afghanistan', USAID. PDF.

Leslie, Jolyon. 2009. 'Culture and Contest', in The Future of Afghanistan, edited by J. Alexander Thier. United States Institute of Peace. Download PDF.

Lister, Sarah. 2007. 'Understanding State-Building and Local Government in Afghanistan', Crisis States Research Centre, Working Paper No. 14. Download PDF.

Lister, Sarah and Andrew Wilder. 2007. 'State-Building at the Subnational Level in Afghanistan: A Missed Opportunity.' Download PDF.

Ludin, Jawad. 2009. 'The Government's Peace Building Attempts 2001-2008', Swedish Committee for Afghanistan Conference: Peace Building in Afghanistan. Download PDF.

Maass, Citha D. 2008. 'A Change of Paradigm in Afghanistan: Afghan Government Ownership Instead of Donor Priorities Source', Stiftung Wissenschaft und Politik, German Institute for International and Security Affairs. Download PDF.

Macdonald, I. 2010. 'Afghanistan's reintegration challenges: land and housing', NOREF. PDF.

Mahmud, Tayyab. 2010. 'Colonial Cartographies and Postcolonial Borders: The Unending War in and around Afghanistan', Link to PDF.

Maley, William. 2011. 'Afghanistan: Grim Prospects?', in America's Challenges in the Greater Middle East: The Obama Administration's Policies. Edited by S. Akbarzadeh. Palgrave. 
Maley, William. 2011. 'The rule of law and the weight of politics: Challenges and trajectories', in The Rule of Law in Afghanistan: Missing in Inaction. Edited by Whit Mason. Cambridge University Press.

Maley, William. 2011. The Role of "International Society" in State-Building: Lessons from Afghanistan', in Enduring States in the Face of Challenges from Within and Without. Edited by Yusuke Murakami et al. Kyoto University Press.

Maley, William. 2011. 'Afghanistan in 2010: Continuing Governance Challenges and Faltering Security', Asian Survey, Vol.51, No.1.

Maley, William. 2008. 'Stabilizing Afghanistan: Threats and Challenges', Carnegie Endowment for International Peace. Download PDF.

Maley, William. 2008. 'Building Legitimacy in Post-Taliban Afghanistan', in State Building, Security, and Social Change in Afghanistan: Reflections on a Survey of the Afghan People. The Asia Foundation. Download PDF.

Marton, Péter and Péter Wagner. 2011. 'Hungary's Involvement in Afghanistan: Proudly Going through the Motions?', in Statebuilding in Afghanistan: Multinational Contributions to Reconstruction. Edited by Nik Hynek and Péter Marton. Routledge.

Matthews, Robert. 2009. 'Afghan Elections 2009: Milestone for Progress or Mirror of Malaise?', Norwegian Peacebuilding Centre. Download PDF.

Medley, Dominic. 2010. 'The Growing Media Landscape in Afghanistan', The RUSI Journal, Vol. 155, No. 1.

Meindersma, Christina. 2007. 'Best Practices for Reconstruction and Development', 2nd Annual Baltic Conference on Defence (ABC/D): NATO in Afghanistan - Facing the Shortfalls and Measuring Success. Download PDF.

Mendel, Jonathan. 2010. 'Afghanistan, Networks and Connectivity', Geopolitics, 15(4).

Michailof, Serge. 2010. 'The challenge of reconstructing 'failed' states: What lessons can be learned from the mistakes made by the international aid community in Afghanistan?', FACTS Reports. Download PDF.

Mielke, K., C. Schetter and A. Wilde. 2011. 'Dimensions of Social Order: Empirical Fact, Analytical Framework and Boundary Concept', ZEF Working Paper, No. 78. PDF.

Mielke, Katja, R. Glassner, C. Schetter and N. Yarash. 2007. 'Local Governance in Warsaj and Farkhar Districts', Amu Darya Series Paper No. 7. Download PDF. 
Mielke, Katja and Conrad Schetter. 2007. "Where Is the Village?" Local Perceptions and Development Approaches in Kunduz Province', Asien 104 (July 2007). Download PDF.

Moore, Rebecca. 2010. 'NATO's partners in Afghanistan: impact and purpose', UNISCI Discussion Papers, No. 22. Download PDF.

Mukhopadhyay, Dipali. 'Warlords As Bureaucrats: The Afghan Experience', Carnegie Endowment for International Peace. Download PDF.

Naylor, Tristen. 2011. 'Deconstructing Development: The Use of Power and Pity in the International Development Discourse', International Studies Quarterly, Vol. 55.

Neumann, Ronald E. 2009. 'Afghanistan: Looking Forward', The Afghanistan Papers, No. 1, June 2009. The Centre for International Governance Innovation. Download PDF.

Nixon, Hamish. 2008. 'Subnational State-Building in Afghanistan', AREU Synthesis Paper Series. Download PDF.

Nixon, Hamish. 2007. 'Aiding the State? International Assistance and the Statebuilding Paradox in Afghanistan', AREU. Download PDF.

Nixon, Hamish and Ponzio, Richard. 2007. 'Building Democracy in Afghanistan: The Statebuilding Agenda and International Engagement,' International Peacekeeping, 14(1).

Noelle-Karimi, Christine. 2006. 'Village Institutions in the Perception of National and International Actors in Afghanistan', Amu Darya Series, Paper No. 1. Download PDF.

Noetzel, Timo. 2011. 'The German politics of war: Kunduz and the war in Afghanistan', International Affairs, Vol. 87, Issue 2.

Open Society Foundations. 2010. 'The Trust Deficit: The Impact of Local Perceptions on Policy in Afghanistan.' Download PDF.

Oxfam. 2009. 'Smart Development in Practice: Field report from Afghanistan', Oxfam America. Download PDF.

Oxfam. 2008. 'Afghanistan: Development and Humanitarian Priorities', Oxfam. PDF.

Pain, Adam and Paula Kantor. 2010. 'Understanding and Addressing Context in Rural Afghanistan: How Villages Differ and Why', AREU. Download PDF.

Parkinson, Sarah. 2010. 'Means to What End? Policymaking and State-Building in Afghanistan', AREU. Download PDF. 
Pauli, Peter et al. 2009. 'National Risk and Vulnerability Assessment 2007/8: A profile of Afghanistan', ICON-INSTITUTE. Kabul, October. Download PDF.

Peavey, Seth \& Khibar Rassul. 2012. 'Opportunities and Challenges for Justice Linkages: Case Studies from Kunduz \& Takhar', CPAU.

Pengelly, Ryan D., and Anne Irwin. 2010. 'Twenty-First Century Narratives from Afghanistan: Storytelling, Morality, and War', in The Routledge Handbook of War and Society: Iraq and Afghanistan. London: Routledge.

Ponzio, Richard and Christopher Freeman. 2007. 'Conclusion: Rethinking Statebuilding in Afghanistan', International Peacekeeping, Vol. 14, No. 1, (January 2007).

Poole, Lydia. 2011. 'Afghanistan: Tracking Major Resource Flows, 2002-2010', Global Humanitarian Assistance briefing paper. Download PDF.

Popal, Jelani. 2009. 'Government Strategies for National and Sub-National Institution Building', Swedish Committee for Afghanistan Conference. Download PDF.

Qassem, Ahmad Shayeq. 2009. 'Afghanistan: Imperatives of Stability Misperceived', Iranian Studies, Vol. 42, No. 2, pp. 247-274.

Rassul, Khibar. 2011. 'Water Scarcity, Livelihood \& Conflict', CPAU. Download PDF.

Riedel, Bruce. 2010. 'Obama's War: Prospects for the Conflict in Afghanistan and Pakistan', The Afghanistan Papers, No. 7. CIGI. Download PDF.

Rietjens, Bas et al. 2009. 'Enhancing the Footprint: Stakeholders in Afghan Reconstruction', Parameters Quarterly, May 2009. Download PDF.

Rietjens, Sebastiaan. 2011. 'Between Expectations and Reality: The Dutch Engagement in Uruzgan', in Statebuilding in Afghanistan: Multinational Contributions to Reconstruction. Edited by Nik Hynek and Péter Marton. Routledge.

Roberts, Adam. 2009. 'Doctrine and Reality in Afghanistan', Survival, Vol. 51, No. 1.

Roberts, Rebecca. 2009. 'Improving Mutual Accountability for Aid Effectiveness' Afghanistan Research and Evaluation Unit. Download PDF.

Roberts, Rebecca. 2009. 'Reflections on the Paris Declaration and Aid Effectiveness in Afghanistan', AREU. Download PDF.

Robinson, Paul. 2010. 'Soviet hearts and minds operations in Afghanistan', The Historian, Vol. 72, No. 1. 
Roi, M. L. and Smolynec, G. 2008. 'End States, Resource Allocation and NATO Strategy in Afghanistan', Diplomacy \& Statecraft, Vol. 9, No. 2.

Roy, Olivier. 2005. 'The predicament of 'civil society' in Central Asia and the 'Greater Middle East', International Affairs, 81, pp. 1001-1012.

Rubin, Barnett R. 2009. 'The Transformation of the Afghan State', in The Future of Afghanistan, edited by J. Alexander Thier. United States Institute of Peace. PDF.

Rubin, Barnett R. 2004. '(Re)Building Afghanistan : The Folly of Stateless Democracy', Current History, Vol. 103, No. 672.

Rubin, B. R. and H. Hamidzada. 2007. 'From Bonn to London: Governance Challenges and the Future of Statebuilding in Afghanistan', International Peacekeeping, 14:1.

Ruparelia, Sanjay and Ruth Rennie. 2008. 'Governance and Development in Afghanistan', in State Building, Security, and Social Change in Afghanistan: Reflections on a Survey of the Afghan People. The Asia Foundation. Download PDF.

RUSI. 2011. 'Afghanistan in transition: Governance, Counter-Corruption and Development: Reshaping Priorities for 2015 and Beyond', Download PDF.

Ruttig, Thomas and Martine van Bijlert. 2011. 'The International Community's Engagement in Afghanistan beyond 2014', Afghanistan Analysts Network. PDF.

Saikal, Amin. 2009. 'Afghanistan: A State in Crisis', in V. Mauer and M. Dunn Cavelty (eds.), The Routledge Handbook of Security Studies. Routledge.

Saikal, Amin. 2008. 'Re-building a Strong State Amidst a Strong Society', CAIS Bulletin, Vol. 15, No. 1, pp. 4,6. Download PDF.

Saikal, Amin. 2005. 'Afghanistan's Weak State and Strong Society', in Making States Work: State Failure and the Crisis of Governance, ed. by Simon Chesterman, Michael Ignatieff and Ramesh Thakur (Tokyo, New York, and Paris), pp. 193-209.

Saltmarshe, Douglas and Abhilash Medhi. 2011. 'Local Governance in Afghanistan: A View from the Ground', AREU. Download PDF.

Schetter, Conrad. 2006. 'The Dilemma of Reconstruction in Afghanistan: International Intervention between the State, Civil Society and Traditional Elites', in Promoting Democracy under Conditions of State Fragility; Issue 1: Afghanistan. Download PDF. 
Schmeidl, Susanne. 2009. 'Prêt-a-Porter States: How the McDonalidization of State-Building misses the Mark in Afghanistan', in M. Fischer and B. Schmelzle (eds) Building Peace in the Absence of States. Berlin: Berghof Research Center. Download PDF.

Schmeidl, Susanne. 2007. 'Civil Society and State-Building in Afghanistan', in Building State and Security in Afghanistan. Edited by Wolfgang Danspeckgruber. Woodrow Wilson School of Public and International Affairs. Download PDF.

Schwartze, Moshe. 2009. 'Department of Defense Contractors in Iraq and Afghanistan: Background and Analysis', CRS Report for Congress. Download PDF.

Shahrani, M. Nazif. 2009. 'Afghanistan's Alternatives for Peace, Governance and Development: Transforming Subjects to Citizens \& Rulers to Civil Servants', The Afghanistan Papers, No. 2. The Centre for International Governance Innovation. PDF.

Shahrani, M. Nazif. 2001. 'Not "Who?" but “How?": Governing Afghanistan after the conflict', Federations (October 2001).

Shannon, Róisín. 2009. 'Playing with principles in an era of securitized aid', Progress in Development Studies, Vol. 9, No. 1.

Sharan, Timor. 2010. 'International Peacebuilding: An Analysis of Peacemaking in Afghanistan', Atlantic Community. Download PDF.

Sharma, Sudhindra and Pawan Kumar Sen. 2008. 'Institutionalization of the Justice System', in State Building, Security, and Social Change in Afghanistan: Reflections on a Survey of the Afghan People. The Asia Foundation. Download PDF.

Siegel, Scott. 2010. 'Learning by Not Doing: Comparative European Experiences in Afghanistan', Western Political Science Association 2010 Annual Meeting. Link.

SIGAR. 2011. 'April 30, 2011 Quarterly Report to Congress', Special Inspector General for Afghanistan Reconstruction. Download PDF.

SIGAR. 2009. 'Contract Oversight Capabilities of the Defense Department's Combined Security Transition Command - Afghanistan (CSTC-A) Needs Strengthening', Special Inspector General of Afghanistan Reconstruction. Download PDF.

Silinsky, Mark. 2010. 'An Irony of War: Human Development as Warfare in Afghanistan', Colloquium, Vol. 3, No. 3. Download PDF.

Smethurst, Mark. 2010. 'Creating Conditions for the Defeat of the Afghan Taliban: A Strategic Assessment', Australian Defence College. Download PDF. 
Spencer, B. and A. Geller. 2009. 'Mobilizing Traditional Afghan Skills and Perceptions to Increase Rural Development and Security', Turkish Policy Quarterly, Summer. PDF.

Stahel, Albert A. 2007. 'Since when has Afghanistan been a "Failed State"?', Politorbis, Vol. 42. Download PDF.

Stanekzai, Mohammad M. 2008. 'Thwarting Afghanistan's Insurgency: A Pragmatic Approach toward Peace and Reconciliation', USIP Special Reports, Issue: 212. PDF.

Stavridis, James G. 2011. 'The Comprehensive Approach in Afghanistan', PRISM 2, No. 2. Download PDF.

Stoddard, Abby et al. 2009. 'Providing Aid in Insecure Environments: 2009 Update Trends in Violence Against Aid Workers and the Operational Response', Overseas Development Institute / Humanitarian Policy Group. Download PDF.

Strand, Arne. 2010. 'When breaking up is hard to do: Exploring exit strategies in Afghanistan', CMI. Download PDF.

Strand, Arne. 2009. 'Faryab Survey: Comparison of Findings from Maymane, 2006 and 2009', CMI Report. Download PDF.

Suhrke, Astri. 2009. 'The Dangers of a Tight Embrace: Externally Assisted Statebuilding in Afghanistan', in Roland Paris and Timothy D. Sisk (Eds.): The Dilemmas of Statebuilding. Confronting the Contradictions of Postwar Peace Operations. Routledge.

Suhrke, Astri. 2007. 'Reconstruction as Modernisation: The 'Post-Conflict' project in Afghanistan', Third World Quarterly, No. 7, 2007: pp. 1291-1308.

Suhrke, Astri. 2007. 'Democratization of a Dependent State: The Case of Afghanistan', CMI Working Paper 2007: 10. Download PDF.

Suhrke, Astri and Kaja Borchgrevink. 2009. 'Negotiating justice sector reform in Afghanistan', Crime, Law and Social Change, Vol. 51, No. 2. Download PDF.

Tadjbakhsh, Shahrbanou. 2009. 'Conflicted Outcomes and Values: (Neo)Liberal Peace in Central Asia and Afghanistan', International Peacekeeping 16(5): 635-651.

Tadjbakhsh, S. 2009. 'Liberal Peace Building and the Challenges to Enhance State Legitimacy', Swedish Committee for Afghanistan Conference: Peace Building in Afghanistan. PDF.

Tadjbakhsh, Shahrbanou. 2008. 'International Peacemaking in Tajikistan and Afghanistan Compared: Lessons Learned and Unlearned', CERIN, No. 143. PDF. 
Thibault, Michael J. et al. 2009. 'Contingency Contracting in Iraq and Afghanistan', Commission on Wartime Contracting in Iraq and Afghanistan. Download PDF.

Thier, J. Alexander. 2010. 'Afghanistan's Rocky Road to Peace', Current History (April).

Thier, J Alexander. 2009. 'A Third Branch?: (Re)establishing the Judicial System in Afghanistan', in Building State and Security in Afghanistan. Edited by Wolfgang Danspeckgruber. Woodrow Wilson School of Public and International Affairs. PDF.

Thiessen, Chuck. 2011. 'NGOs and post-violence community development: holistic, multi-track ventures in Afghanistan', Development in Practice, Vol. 21, No. 7.

3D Security. 2009. 'Civil Society Perspectives on US Policy in Afghanistan', 3D Security // Development Diplomacy Defense. Download PDF.

Tierney, John F. 2010. 'Warlord, Inc.: Extortion and Corruption Along the U.S. Supply Chain in Afghanistan', U.S. House of Representatives. Download PDF.

TLO. 2009. 'Tribal Jurisdiction and Agreements The Key to Sub-National Governance in Southeastern Afghanistan', Tribal Liaison Office Policy Brief. PDF.

TLO. 2009. 'Linkages between state and non-state justice systems in Eastern Afghanistan evidence from Jalalabad, Nangarhar and Ahmad Aba, Paktia', TLO. Download PDF.

TLO. 2009. 'Between the Jirga and the Judge: Alternative Dispute Resolution in Southeastern Afghanistan', TLO Program Brief/1. Download PDF.

Tondini, Matteo. 2009. 'Justice Sector Reform in Afghanistan: From a 'Lead Nation' Approach to a 'Mixed Ownership' Regime?', Transit Stud Rev, 15: 660-673.

Tondini, Matteo. 2008. 'From Neo-Colonialism to a 'Light-Footprint Approach': Restoring Justice Systems', International Peacekeeping, 15:2, pp. 237-251.

Uesugi, Yuji (editor). 2009. Toward Bringing Stability in Afghanistan: A Review of the Peacebuilding Strategy. IPSHU English Research Report Series No.24. PDF.

Ulriksen, Ståle. 2010. 'Norway's political test in Faryab, Afghanistan: how to lead?', NOREF. Download PDF.

Ulriksen, Ståle. 2010. 'Norway's strategic challenges in Afghanistan: how to make a difference?', NOREF. Download PDF.

UN. 2011. 'The situation in Afghanistan and its implications for international peace and security', Report of the Secretary-General. Download PDF. 
UN. 2010. 'The Situation in Afghanistan and Its Implications for International Peace and Security: Report of the Secretary General', UN Security Council. Download PDF.

UNODC. 2010. 'Corruption in Afghanistan: Bribery as reported by the victims.' PDF.

US Senate. 2011. 'Evaluating U.S. Foreign Assistance to Afghanistan.' PDF.

Vlad, Liviu Bogdan and Adina Negrea. 2009. 'Afghanistan: Post-Modernizing a Pre-Modern Society?', Romanian Journal of European Affairs, Vol. 9, No. 3. Download PDF.

Wafaey, Hassan and Anna Larson. 2010. 'The Wolesi Jirga in 2010: Pre-election Politics and the Appearance of Opposition', AREU. Download PDF.

Wagner, Christian. 2010. 'Governance in Afghanistan in Regional Perspective', Afghanistan Analysts Network. Download PDF.

Wahidi, Sayed Maisam. 2011. 'Tackling Corruption and Aid Management in Afghanistan', CAPS. Download PDF.

Waldman, Matt. 2008. 'Falling Short: Aid Effectiveness in Afghanistan', ACBAR Advocacy Series. Download PDF.

Walker, Elizabeth Lee. 2010. 'Culturally-Attuned Governance and Justice in Helmand Province, Afghanistan', International Media Ventures/ISAF. Download PDF.

Wardak, A. 2009. 'Rule of Law in Afghanistan' in LISD Petersberg Papers on Afghanistan, Liechtenstein Institute on Self-Determination, Princeton University.

Wardak, A. 2009. 'Rebuilding the Justice System in Afghanistan: Problems and Prospects', EuroAtlantic Quarterly, Vol. 16.

Wardak, Mirwais. 2009. 'Regaining People's Confidence - Strategies to Enhance State Legitimacy and Civil Society', Swedish Committee for Afghanistan Conference. PDF.

Whitty, Brendan and Hamish Nixon. 2009. 'The Impact of Counter-Terrorism Objectives on Democratization and Statebuilding in Afghanistan', Taiwan Journal of Democracy, Vol. 5, No.1. Download PDF.

Wilder, Andrew and Sarah Lister. 2007. 'State-Building at the Subnational Level in Afghanistan: A Missed Opportunity', in Building State and Security in Afghanistan. Edited by W. Danspeckgruber. Woodrow Wilson School. Download PDF. 
Williams, M.J. 2011. 'Empire Lite Revisited: NATO, the Comprehensive Approach and Statebuilding in Afghanistan', International Peacekeeping, Vol. 18, Issue 1.

Wilton Park Conference. 2010. 'Winning 'hearts and minds' in Afghanistan: assessing the effectiveness of development aid in COIN operations', Report on Conference. Download PDF.

Winter, Elizabeth. 2010. 'Civil Society Development in Afghanistan', LSE. PDF.

Zyla, Ben. 2011. '(Chapter on Canada)', in Statebuilding in Afghanistan: Multinational Contributions to Reconstruction. Edited by Nik Hynek and Péter Marton. Routledge. 
Neighbors and Regional Dynamics: Iran, Pakistan, India, Russia and Central Asia

AIAS. 2009. 'Afghanistan's Other Neighbors: Iran, Central Asia and China Conference Report', Organized by the American Institute of Afghanistan Studies and the Hollings Center for International Dialogue. Istanbul, Turkey. July 2008. Download PDF.

Fair, C. Christine. 2010. 'India in Afghanistan and Beyond: Opportunities and Constraints', Century Foundation Report. Download PDF.

Foust, Joshua. 2010. 'Post-Soviet Central Asian National Interests in Afghanistan', Century Foundation Report. Download PDF.

Gleason, Gregory. 2011. 'Transit Agreements, Security Cooperation and Afghanistan Stabilization', OSCE Central Asia Security Policy Brief \#5. Download PDF.

Gleason, Gregory, Reuel R. Hanks and Yury Bosin. 2009. 'Afghanistan reconstruction in regional perspective', Central Asian Survey, Volume 28, Issue 3.

Gohel, Sajjan M. 2010. 'Iran's Ambiguous Role in Afghanistan', CTC Sentinel, Vol. 3, No. 3. Download PDF.

Hanif, Melanie. 2009. 'Indian Involvement in Afghanistan: Stepping Stone or Stumbling Block to Regional Hegemony?', German Institute of Global and Area Studies. PDF.

Harpviken, Kristian Berg, 2010. 'Afghanistan in a Neighbourhood Perspective: General Overview and Conceptualisation', PRIO Paper. Download PDF.

Hasnat, Syed. 2009. 'Pakistan's Strategic Interests, Afghanistan and the Fluctuating U.S. Strategy', Journal of International Affairs, Vol. 63, No. 1.

Humayoon, Haseeb and Marvin G. Weinbaum. 2009. 'The Intertwined Destinies of Afghanistan and Pakistan', in The Future of Afghanistan, edited by J. Alexander Thier. United States Institute of Peace. Download PDF.

Kagan, Frederick W., Kimberly Kagan and Danielle Pletka. 2008. 'Iranian Influence in the Levant, Iraq, and Afghanistan', American Enterprise Institute. Download PDF. 
Khan, Ayesha R. 2010. 'Conceptualizing AfPak: The Prospects and Perils', Chatham House Programme Paper. Download PDF.

Lin, Christina. 2011. 'China's Silk Road Strategy in AfPak: The Shanghai Cooperation Organization', ISPSW, Berlin. Download PDF.

Lunn, John and Ben Smith. 2010. 'The 'AfPak policy' and the Pashtuns', UK House of Commons Library. Download PDF.

Maley, William. 2009. 'Afghanistan and Its Region', in The Future of Afghanistan, edited by J. Alexander Thier. United States Institute of Peace. Download PDF.

Misra, Amalendu. 2009. 'Afghanistan - The Regional Dimension', in Afghanistan: Now You See Me? IDEAS Strategic Update 001. March 2009. Download PDF.

Munson, Mark. 2009. 'Should AF/PAK Hands be South Asia Hands? How the India-Pakistan Relationship Shapes the War in Afghanistan', Small Wars Journal, December. Download PDF.

Nader, Alireza and Joya Laha. 2011. 'Iran’s Balancing Act in Afghanistan', RAND. PDF.

$\mathrm{Ng}$, Tiffany. 2010. 'China's Role in Shaping the Future of Afghanistan', Carnegie Foundation, Policy Outlook. Download PDF.

Pant, V. Harsh. 2010. 'India's challenge in Afghanistan: with power comes responsibility', CASI Working Paper. Download PDF.

Sadat, M. H. 2010. 'U.S.-Iran Engagement Through Afghanistan', Middle East Policy, 17(1).

Saikal, Amin. 2007. 'The Afghanistan-Pakistan Border and Afghanistan's Long-Term Stability', in Building State and Security in Afghanistan. Edited by Wolfgang Danspeckgruber. Woodrow Wilson School of Public and International Affairs. PDF.

Shahid, Shiza. 2009. 'Engaging Regional Players in Afghanistan: Threats and Opportunities', Center for Strategic and International Studies. Download PDF.

Sharma, Raghav. 2008. 'Afghan Cauldron: Achieving India's Interests', IPCS Issue Briefs, Issue 82. Download PDF.

Szlajfer, Henryk, et al. 2010. 'Future Scenarios for the Conflict in Afghanistan: A Regional Perspective', Centre for International Relations. Download PDF.

Tadjbakhsh, Shahrbanou. 2011. 'The Robust India-Pakistan Rivalry', PRIO. PDF. 
Tellis, Ashley J. et al. 2010. 'Is a Regional Strategy Viable in Afghanistan?', Carnegie Endowment for International Peace. Download PDF.

Torjesen, Stina and Tatjana Stankovic. 2010. 'Regional Change: How will the rise of India and China shape Afghanistan's stabilization process?', NUPI. Download PDF.

Trenin, Dmitri and Alexei Malashenko. 2010. 'Afghanistan: A View From Moscow', Carnegie Endowment for International Peace. Download PDF.

US Senate. 2011. 'Central Asia and the transition in Afghanistan', Committee on Foreign Relations. PDF.

Wilde, Andreas. 2009. 'Continuity and Hiatus: Structural Patterns of Iran's Policy in Afghanistan', Internationales Asienforum, Vol. 40, No. 1-2. Download PDF.

Wilkens, Ann. 2009. 'Relations between Pakistan and Afghanistan', in Kristina Zetterlund (ed.), Pakistan - Consequences of Deteriorating Security in Afghanistan. Stockholm: FOI (Swedish Defence Research Agency). Download PDF.

Yousafzai, Rahim Ullah. 2011. 'Pakistan-Afghanistan Relations: A Pakistani Narrative', Pakistan Institute of Legislative Development and Transparency. PDF.

Yusuf, Moeed W. 2010. 'The U.S.-Pakistan Relationship and Finding an End State in Afghanistan', CTC Sentinel, Vol. 3, No. 9. Download PDF. 